San Jose State University

SJSU ScholarWorks

Master's Theses

Master's Theses and Graduate Research

Fall 2009

\title{
Information management professionals and programs in U.S. architecture firms.
}

Lynne M. Kemmer

San Jose State University

Follow this and additional works at: https://scholarworks.sjsu.edu/etd_theses

\section{Recommended Citation}

Kemmer, Lynne M., "Information management professionals and programs in U.S. architecture firms." (2009). Master's Theses. 3998.

DOI: https://doi.org/10.31979/etd.ekqp-4eye

https://scholarworks.sjsu.edu/etd_theses/3998

This Thesis is brought to you for free and open access by the Master's Theses and Graduate Research at SJSU ScholarWorks. It has been accepted for inclusion in Master's Theses by an authorized administrator of SJSU ScholarWorks. For more information, please contact scholarworks@sjsu.edu. 
INFORMATION MANAGEMENT

PROFESSIONALS AND PROGRAMS

IN U.S. ARCHITECTURE FIRMS

\begin{abstract}
A Thesis
Presented to

The Faculty of the School of Library and Information Science

San José State University

\author{
In Partial Fulfillment \\ of the Requirements for the Degree \\ Master of Library and Information Science
}

by

Lynne M. Kemmer

December 2009 
UMI Number: 1484354

All rights reserved

INFORMATION TO ALL USERS

The quality of this reproduction is dependent upon the quality of the copy submitted.

In the unlikely event that the author did not send a complete manuscript and there are missing pages, these will be noted. Also, if material had to be removed, a note will indicate the deletion.



UMI 1484354

Copyright 2010 by ProQuest LLC.

All rights reserved. This edition of the work is protected against unauthorized copying under Title 17, United States Code.

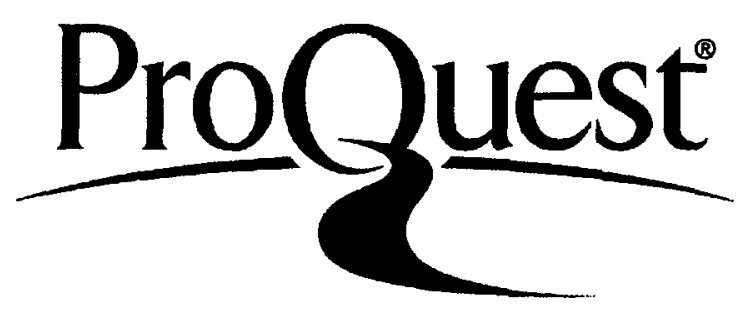

ProQuest LLC

789 East Eisenhower Parkway

P.O. Box 1346

Ann Arbor, Ml 48106-1346 
(C) 2009

Lynne M. Kemmer

ALL RIGHTS RESERVED 


\section{SAN JOSE STATE UNIVERSITY}

The Undersigned Thesis Committee Approves the Thesis Titled

INFORMATION MANAGEMENT

PROFESSIONALS AND PROGRAMS

IN U.S. ARCHITECTURE FIRMS

by

Lynne Margaret Kemmer

APPROVED FOR THE SCHOOL OF LIBRARY AND INFORMATION SCIENCE

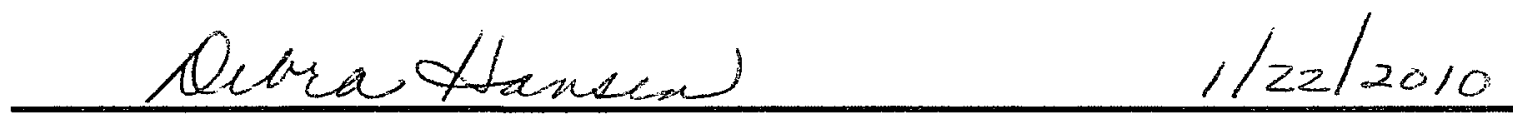

Dr. Debra Hansen, School of Library and Information Science Date

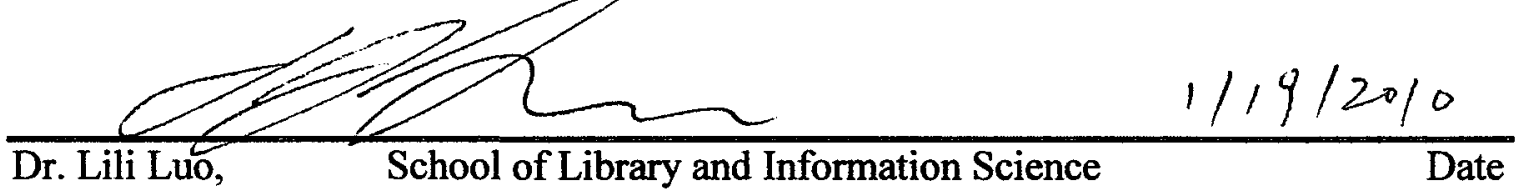

$\frac{\text { Chaclate Fre }}{\text { Dr. Charlotte Ford, Birmingham-Southern College }} 1 / 15 / 10$

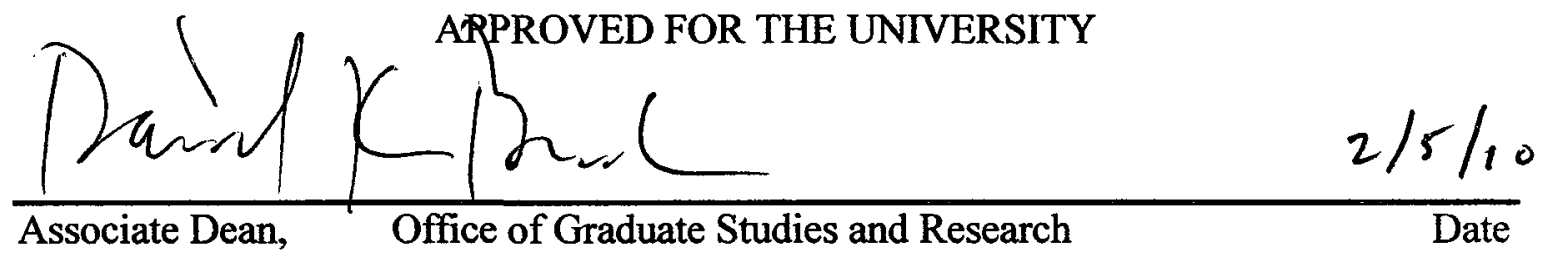




\section{ABSTRACT \\ INFORMATION MANAGEMENT \\ PROFESSIONALS AND PROGRAMS \\ IN U.S. ARCHITECTURE FIRMS \\ by Lynne M. Kemmer}

This research study identifies an active population of librarians and information management (IM) professionals and describes library and IM programs in architectural design firm offices in the United States. The levels of education, job titles, and duties of the professionals managing and assisting with the libraries and IM programs are clarified. Designated spaces, budgets, resources, systems, services, evaluation, and communication methods for the libraries and IM programs, are determined. The information needs of management and employees in the architecture firms are specified. The support materials the librarians and IM professionals utilize to administer their library and IM program's resources and services are ascertained. Librarians and IM professionals discuss whether they feel the existing professional literature, training materials, and other sources support their architectural IM work.

Recent downturns in the economy have adversely affected the presence of employed librarians and existence of libraries in architectural design firm offices. Nonetheless, surges in design firm revenue in the past combined with the development of new technologies and a lack of current research and data on this special library population make this study timely and significant. Being exploratory in nature, however, the findings should be considered as setting the stage for further research in this special sphere of library work. 


\section{ACKNOWLEDGEMENTS}

Very special thanks to Dr. Debbie Hansen for jumping in and filling the role of thesis chair in my 11th hour. Without Debbie's unwavering support this thesis would not have been completed with the same level of usefulness. I want to also thank my other thesis committee members who have all contributed to the development of this study over time: Dr. Charlotte Ford, Dr. Lili Luo, Professor Joe Matthews, and Dr. Sue Alman. My most heartfelt gratitude goes to my family who has supported me through this process, and the long and winding road of obtaining my MLIS. Finally, a thank you to all of those behind the scenes in Graduate Studies and the School of Library and Information Science at San Jose State who facilitated this research process along the way, and who also believed it would be a meaningful contribution to the library field. 


\section{Table of Contents}

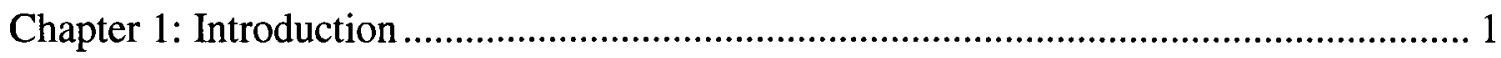

The Field of Architecture .................................................................................. 1

Architectural Libraries .............................................................................. 1

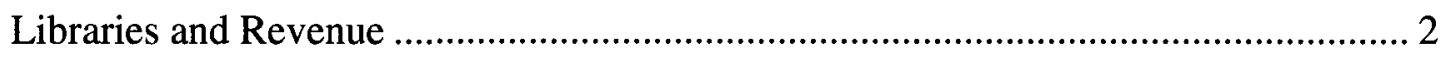

Information Management in Architecture Firms ............................................ 4

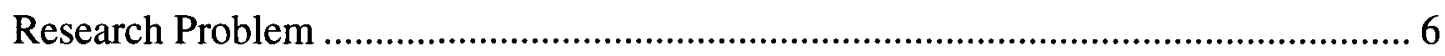

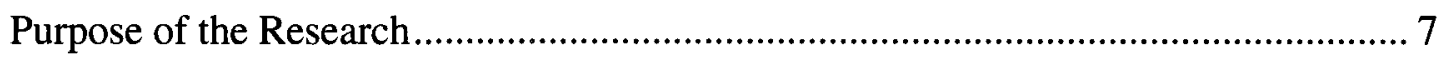

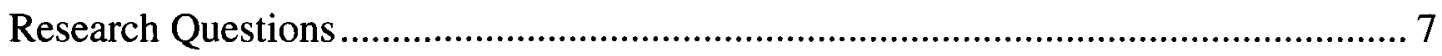

Chapter 2: Review of the Literature .................................................................. 9

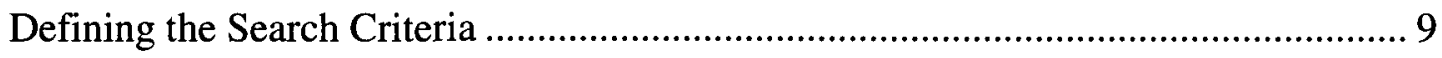

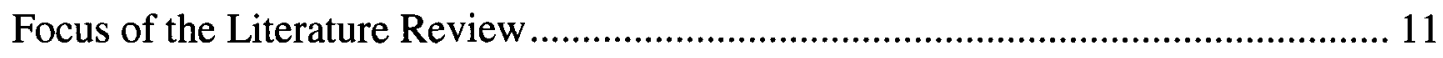

Data and Statistics on Architectural Design Firm Libraries and Librarians ............. 12

Research Studies on Architectural Libraries and Librarians ................................. 15

Professional Sources Developed for Architectural Design Firm Library Managers .. 17

Other Literature About Architectural Design Firm Library Practice........................ 19

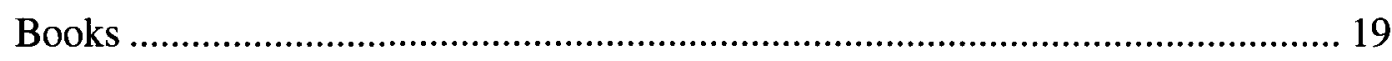

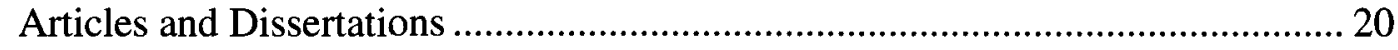



What the Literature Reveals About Architectural Design Firm Libraries ................. 21

Architects and Librarians ...................................................................... 22

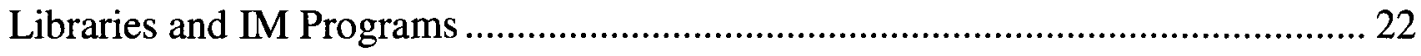




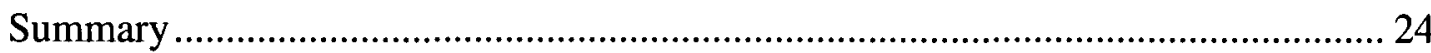

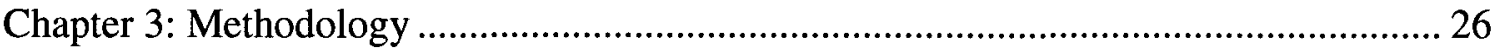



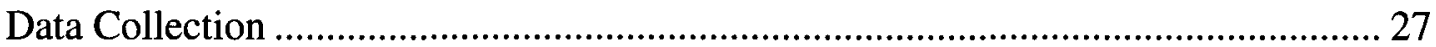





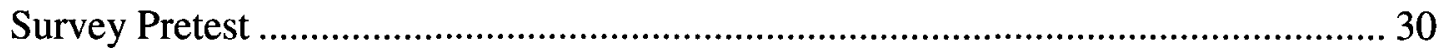

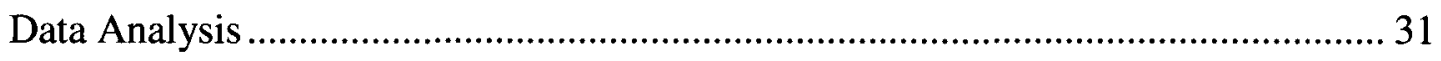

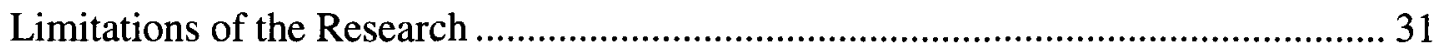

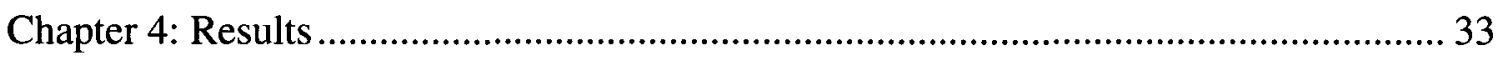

Phone Inquiry

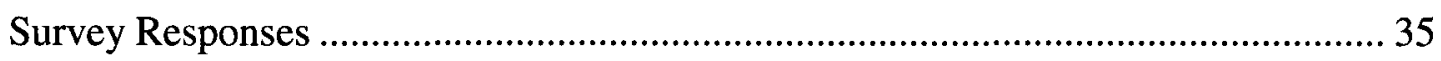

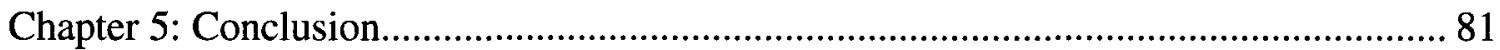

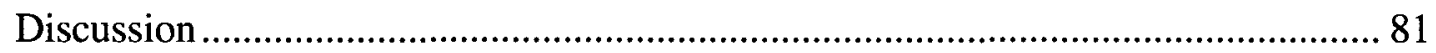

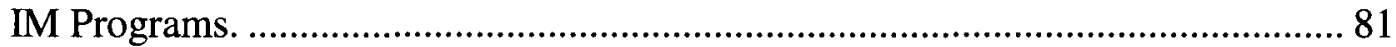

Space.

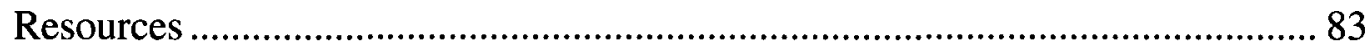

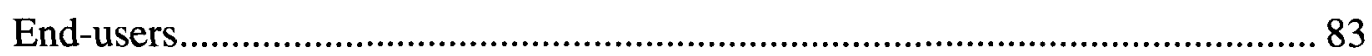

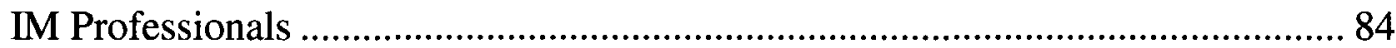

Level of Support for IM Professionals............................................................... 87

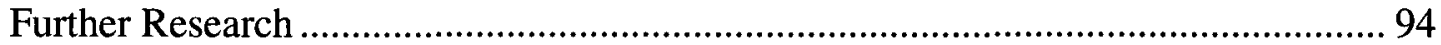

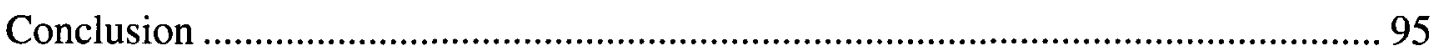






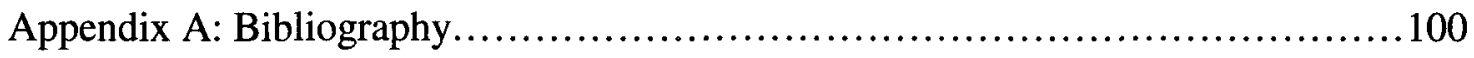

Appendix B: Resource Directors Association (RDA) Job Description................ 105

Appendix C: Research, Data, Statistics..................................... 106

Appendix D: Professional Associations......................................110

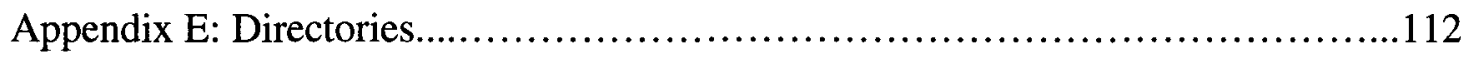

Appendix F: Survey Instrument..............................................113

Appendix G: Phone Script.................................................130

Appendix H: Cover Letter................................................. 132 


\section{LIST OF TABLES}

Table 1 Library and Information Management Programs Reported in Firms Ranked on Architectural Record List.

Table 2 Librarians and Information Management Professionals Reported in Firms

Ranked on Architectural Record List

Table 3 Frequencies of Primary, Secondary, And Tertiary Job Titles Held by Survey

Respondents 36

Table 4 Frequency Distribution of Education Level of Survey Respondents 39

Table 5 Frequency Distribution of Library Science Degrees Among Survey

Respondents

Table 6 Frequency Distribution of Names of Survey Respondents' Information in

Survey Management Program(s)

Table 7 Frequency Distribution of Names of Other Information Management

Programs in Survey Respondents Offices...

Table 8 Frequency Distribution of Staffing Levels for Survey Respondents'

Information Management Program(s)

Table 9 Frequency Distribution of Paid Time Per Week For Staff of Information

Management Program(s)

Table 10 Frequency Distribution of Tools and Resources Utilized in Survey

Respondents' Information Management Program(s)

Table 11 Frequency Distribution of Survey Respondents' Information Management

Job Duties 
Table 12 Frequency Distribution of Functions of Survey Respondents' Information

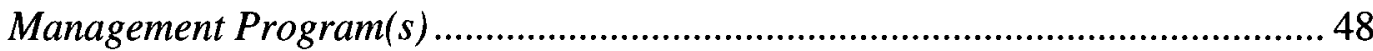

Table 13 Frequency Distribution of Survey Respondents' Perceptions of Professional Support Materials For Information Management Professionals in Architecture Firms 50

Table 14 Professional Support Materials Survey Respondents Would Like to See Developed For Information Management Professionals in Architecture Firms

Table 15 Descriptive Statistics For Survey Respondents' Ratings of Support Materials For Information Management Professionals in Architecture Firms 54

Table 16 Frequency Distribution of Existence or Absence of Budget For Survey Respondents' Information Management Program(s) 55

Table 17 Frequency Distribution and Descriptive Statistics For Number of Years of Existence of Survey Respondents' Information Management Program(s) or Services in Their Firm Offices... 56

Table 18 Frequency Distribution and Descriptive Statistics For Estimates of Square Footage Dedicated to Survey Respondents' Information Management Program(s) in Their Firm Offices 61

Table 19 Frequency Distribution of Access and Storage Tools For Survey Respondents' Information Management Program's(s') Resources And Services 
Table 20 Frequency Distribution For Firm Offices And Number of End-users Served by Survey respondents Information Management Program(s) 64

Table 21 Frequency Distribution of Use of Survey Respondents Information

Management Program(s) by Occupational Category 66

Table 22 Descriptive Statistics For Occupational Categories Use of Survey

Respondents' Information Management Program(s)

Table 23 Frequency Distributions For Primary Information Needs by Occupational

Category

Table 24 Percentages of Primary Information Needs by Occupational Category 73

Table 25 Frequency Distribution For Survey Respondents' Methods of Determining

Information Needs of The End-users of Their Information Program(s).

Table 26 Frequency Distribution For Survey Respondents' Methods of Evaluating or

Measuring The Value of Their Information Management Program(s) or

Services 76

Table 27 Methods Survey Respondents' Use to Communicate News About Their Information Management Program(s) to Management And Employees in Their Firm

Table 28 Professional Associations Survey Respondents Have Joined to Support Their Architecture Firm Information Management Work 79 


\section{Chapter 1}

\section{Introduction}

\section{The Field of Architecture}

Great civilizations have been cemented in time in part by the architecture that has marked their presence; some examples are the Greek, Roman, and Mayan temples, as well as the Egyptian pyramids. In the early eras, the architects and engineers who designed these monumental structures served royal patrons (Mount, 1982) and, later, government and clergy. As world populations have multiplied over time, however, the need for design and construction expertise has permeated every level of our global society. To meet the increasing demand, architects and engineers ventured out on their own to work for civilian sponsors (Mount, 1982). Now we see the existence of multidisciplinary design firms that employ engineers, architects, and interior designers, all under one roof. Archives, libraries, and information programs with other names have been incorporated into these design firms to streamline better business practice by organizing and providing access to the firm's intellectual property and collective knowledge, as well as providing information resources that foster the creativity and continuing education of the employees.

\section{Architectural Libraries}

William Robert Ware introduced the first architecture library in America in 1865 as part of a plan of study for the formal education of architects at the Massachusetts Institute of Technology (Shillaber, 1954). Academic, public, industrial, technical, and society-sponsored libraries were established in New York in the late 19th century to 
support the information needs of engineers (Mount, 1982). The number of academic architectural libraries is duly noted in academic library literature. Today there are over 100 architecture libraries in existence in the United States, some of which are located at noteworthy academic institutions such as Princeton and Harvard. These architecture libraries exist to support the architecture students and programs, the architecture field, and to preserve information about our architectural heritage. However, in stark contrast there is seemingly very little information about architectural design firm libraries despite the fact that they are known to exist, a point that is reflected in 25 or so design firm library listings in the Thomson Gale (2007) Directory of Special Libraries and Information Centers, and by their presence in numerous library-related professional association membership rosters. It is possible that the number of library programs and librarians in architectural firms have been so low that they did not garner much attention in the form of research or reporting in the past; however, it is being proposed here that they warrant more consideration today. It is possible that the advent of new technology and surges in design firm industry revenue over time, as well as a proprietary need to capture and organize intellectual property and other resources that facilitate a competitive advantage, may have given rise to the establishment of more architectural design firm libraries or information management (IM) programs, as well as employment of librarians or other IM professionals to manage or assist with the programs.

\section{Libraries and Revenue}

Shaw (1995) reported that architectural and design firm librarians stated the future of design firm libraries is "linked to the overall economic trends in building and 
construction" (p. 156). Gary Tulacz, Senior Editor for ENR, confirmed that the demand for "one-stop shopping has given rise to multidisciplinary design firms" (personal communication, August 16, 2007), and business has been booming (Engineering News-Record [ENR], 2006). The U.S. Census Bureau's Service 2000-2004 Annual Survey (SAS) reported an increase in architectural, engineering and related services revenue in millions of dollars, from $\$ 150,269,000$ in 2000 to $\$ 180,074,000$ in 2004 . Interior design services increased in millions, from $\$ 6,798,000$ in 2000 to $\$ 8,061,000$ in 2004 (U.S. Census Bureau, 2006). The U.S. Department of Labor's Bureau of Labor Statistics (BLS) Occupational Outlook Handbook reported projected increases in employment of architects and interior designers from 9\% to 17\% through 2014 (BLS, 2007).

McGraw-Hill's annual "Top 500 Design Firms" list, published in one of its trade journals titled, Engineering News-Record (ENR; 2007), reports an increase in design firm revenue between 2004 and 2006. In 2006 alone, the "Top 500 Design Firms" as a group accounted for $\$ 69.61$ billion dollars in design revenue, $17.5 \%$ above the $\$ 59.25$ billion reported in 2005, and 31.4\% higher than 2004 (ENR, 2007). Fortune magazine's "Fortune 500" list shows the "Engineering, Construction" group, which includes architecture according to Senior List Editor at Fortune, Cullen Wheeler, (personal communication, September 6, 2007), ranked 41st under "Most Profitable Industries" in 2005, and 44th in 2006 (CNNMoney, 2007). In addition, the same group ranked fifth in the 2006 “Top Industries, Fastest Growing Industries: Growth in Revenue" category, with total profit as percent of revenue at $21.8 \%$, and at seventh in 2005 with $23.2 \%$ total 
profit as percent of revenue (CNNMoney, 2007). Recent economic downturns have adversely affected the building and construction industries, and architecture firms in turn, but many firms that are focusing on medical and government markets in which demand for building and design services has not waned, have continued to thrive.

According to the results of a study conducted by the Special Library Association (SLA) in $1998,63 \%$ of the Fortune 500 companies had libraries, and $85 \%$ of the top 100 had libraries or information centers (SLA, 1998). In addition, the study found that the higher the corporation ranked in the Fortune 500 list the "significantly more likely they would have a corporate library or information center" (SLA, 1998). The results of the SLA study suggest that corporate architectural design firm offices that generate more revenue may be more likely to support an in-house library or IM program and possibly also dedicate a professional to manage or assist with administering the resources and services.

\section{Information Management in Architecture Firms}

Firm library consultant and librarian Radonsky (1991) stated that "a well-organized library can significantly affect a firm's success and longevity" (p. 1). Brown (2001), former President of Skidmore, Owings, and Merrill architectural design firm, stated "Architecture has many of the characteristics that Business Week says the world's top-rung companies will share in 21 st century. It will be based in information and talent. Top-rung companies will be focused on leveraging of intellectual capital and human knowledge" (Brown, 2001, p.15). Brown (2001) reported that "it is killing firms not to manage their collections effectively" (p. 15). Kanoglu and Arditi (2001) describe 
how the lack of effective information systems in design firms led them to develop a computer-based information system called ASAP that incorporates library, communication, and archive modules that at the time of the article's publication was being utilized by nine architectural offices. Sanders (1997), Associate Partner at Zimmer Gunsel Frasca, reported that more and more architectural firms such as Hellmuth, Obata \& Kassabaum (HOK) and Naramore, Bain, Brady and Johanson (NBBJ) were also incorporating Intranet systems to manage their knowledge bases and that there would be a need for "gatekeepers" to be designated by the firms to be responsible for the organizational framework and content. Mays (1997), Director of Technology at HOK, quotes principal architect Paul Doherty as stating that firms often archived firm data with third parties to maximize speed of in-house systems. However, they are also linking to Extranets via in-house Intranet systems equipped with external ports to also share information with outside organizations.

The integration of newer information technologies in design firm offices may also indicate that more trained librarians or IM professionals are employed or in demand to design or streamline information systems, as well as organize, update and provide access to their content and services. On the other hand, it may be that these systems are replacing a need for physical libraries and library managers. Despite what may be a focus on acquiring digital information in many architectural design firm offices, the need to store and provide access to the intellectual property generated and acquired in hard copy formats such as presentation materials, drawings and plans, books, magazines, and 
vendor samples, does require designation of space and, in a best case scenario, a knowledgeable professional to manage the resources.

\section{Research Problem}

Due to what appears to be a lack of evidence-based research, one can only guess at how prevalent libraries and IM programs are in architectural design firm offices or how many librarians and other professionals are managing or assisting with them. One can only conjecture about the types of resources and services that are currently provided and how they are delivered. One can only presume that the people in charge feel the existing professional literature, training materials, and other sources are sufficient to support them in their ability to administer or assist with the programs.

A portion of the SLA's Research Statement reads on their Web site as follows: "In this new environment, it is more important than ever to build our knowledge base and to use evaluation research methods to constantly monitor and improve the quality of the services provided" (SLA, 2009, para.10). The SLA realizes the importance of identifying populations of special library professionals and the organizations they serve. As prior Chairman of their Committee on New Special Libraries, Christianson (1980) maintains one of SLA's goals is to "provide the basic dimensions of the universe for further research" (p. 147). This research study seeks to fulfill this mandate by providing the basic dimensions of architectural design firm library and IM practice so further evaluation research can be conducted and the quality of the program services that are provided can be better supported and ultimately improved. 


\section{Purpose of the Research}

This investigation describes library and IM roles and responsibilities as well as current library and IM programs' functions in architectural design firm offices in the United States. The data collected establishes a sample population of architecture firms that support a library or IM program and dedicate a professional to manage or assist with administering library or IM resources and services. Job titles and job responsibilities as well as the levels of education of the professionals in charge of managing and assisting with IM programs are ascertained. Designated spaces, budgets, resources, systems, services, evaluation and communication methods are all clarified. The information needs of management and other firm employees are explored. The support materials the IM professionals utilize to effectively set-up and administer their programs as well as to provide resources and services are also identified. Finally, the librarians and IM professionals report on whether they perceive the existing professional literature, training materials, and other sources to be supportive of their architectural IM work.

\section{Research Questions}

In order to gain a deeper understanding of this special library population the research questions are as follows:

1. What kinds of libraries and IM programs exist in U.S. architectural design firm offices and what types of resources and services do they provide?

2. Who is in charge of managing or assisting with the libraries or IM programs in U.S. architectural design firm offices and what are their job responsibilities? 
3. Do the professionals who manage or assist with the libraries and IM programs perceive the existing professional literature, training materials and other sources as sufficient to support their ability to administer or assist with the programs, resources and services?

The research questions that have been developed fulfill the purpose of this research in that they investigate unexplored special library environments in architectural design firm offices. Programs, resources, services, and how they are delivered, as well as who is in charge and their specific job duties, are revealed. In addition, the professionals that are identified as in charge or assisting with the programs report on the professional sources they feel are helpful or not, and also specify what they would like to see developed to better support them in the future.

The significance of the information presented here is that it makes an original and meaningful contribution to the knowledge base of the library science field, and paves the way for more value-based research to be done in the future. It is hoped that the findings of this research may facilitate opportunities for professional and academic library science communities to introduce library science courses that address this type special library practice, and to possibly also develop more relevant library-related support materials for architectural design firm librarians and IM professionals in the future. Finally, the presentation of this special library work may raise awareness about career opportunities in this field for library science students and library professionals. 


\section{Chapter 2: Review of the Literature}

\section{Defining the Search Criteria}

Disparity in job titles of librarians and IM professionals, as well as types of libraries and IM programs in design firm environments may call for leaders in the library and information science field to further acknowledge, define, and distinguish library and IM practice in the architecture industry.

Shaw (1995) states "architecture is an art, a science and a business" (p. 152). The search for literature about libraries in architecture firms is complicated for many reasons. Academic libraries are not generally considered to be special libraries; however, academic architectural libraries are often grouped with corporate design firm libraries in professional associations with an "architectural" focus, as well as in library directories, indexes, and other reference sources. Many architects also work in the same office with Engineers so libraries and IM programs may serve one or more disciplines. Engineering libraries in academic and corporate settings are found to be categorized under "Science and Technology" or "Science and Engineering" libraries. Many architecture firms also maintain archives to store and provide access to drawings and plans and other materials. Archives are generally considered a separate discipline in the library field, but can be a component of library practice in academic, special, and corporate environments. Finally, design firm records departments are often their own entity in lieu of, or in addition to, having a library or information center. Therefore, design firm offices may support one library that serves the needs of varied professional categories, or two or more libraries 
that serve more specific categories, in addition to also having archives and records departments.

Design firm libraries are also grouped in "special" and "corporate" library literature and further categorized as "Art Libraries" within those contexts. The art library categorization yields the most relevant results on the subject of architectural design firm libraries. The International Federation of Library Associations (IFLA) describes art libraries on its Web site as "concerned with all formats of textual and visual documentation for the visual arts, including fine arts, applied arts, design and architecture" (IFLA, 2009, para. 1 ). The SLA Guide for Special Library Management states that the terms "library" and "information center" are often used interchangeably (SLA, 1986), and many of the industry reports currently posted on the SLA Web site use the term "information management" in lieu of the more traditional "library" term. According to Ahrensfeld, Christianson and King (1986), information centers are thought to be more sophisticated and provide broader functions.

Terms such as technical, knowledge, materials, research and resource centers also appear in the literature and online sources. The International Interior Design Association (IIDA) and American Society of Interior Designers (ASID) have established virtual "knowledge centers" on their Web sites to provide information and research services for members. The Thomson Gale (2007) Directory of Special Libraries and Information Centers lists numerous names for the libraries and IM programs including design, technical, research, resource and materials libraries; information, knowledge, research and resource centers; and simply libraries and archives. In addition, the directory 
organizes these programs together with nonprofit and historic architecture libraries, as well as with academic architecture libraries. To make sure to acknowledge the variance, the terms "libraries" and "IM programs" are used interchangeably throughout the course of this research.

The titles of the professionals in charge of the libraries and information programs in the Thomson Gale (2007) Directory of Special Libraries and Information Centers are as varied and extensive as the names. The job title of simply "librarian" is dominant, but one will also find corporate librarian, archival librarian, information director, information resource librarian, information specialist, information services manager, library administrator, library service manager, resource coordinator, resource director and manager. The Resource Directors Association (RDA), an association of architecture and design firm resource professionals, currently posts the job responsibilities of what they refer to as a "resource librarian" on their Web site (see Appendix B). To make sure to address the variance here, the terms "librarian" and "IM professional" are also used interchangeably throughout the course of this study.

\section{Focus of the Literature Review}

The primary focus of this literature review for the purpose of this research study is on libraries and librarians in architectural design firm offices. More specifically the focus was placed on the following: (a) to attempt to locate statistics and research on the number of architectural design firm libraries and IM programs and librarians or IM professionals to derive a sample population; (b) to determine if a similar study had been conducted; (c) to locate existing support materials for the librarians and IM professionals who manage 
and assist with the programs; and (d) to locate information about the librarian and other IM roles, as well as libraries and IM program functions, in architectural design firm offices. Information on the more generic corporate or special libraries, or on the available resources for the end-users in the architecture offices, is not the concentration of this literature review.

\section{Data and Statistics on Architectural Design Firm Libraries and Librarians}

Shaw (1995) reported in 1993-1994 that there were over 20,000 architectural design firms in the United States, and 45 had a staff member registered with the Association of Architectural Librarians (AAL). Jamie Back, Statistical Analyst for the U.S. Department of Commerce Census Bureau, reports that 25,331 firms offer architecture services in the United States today (personal communication, October 6, 2009). On the American Institute of Architects (AIA) Web site (2009), it is reported that members own 17,600 architecture firms.

Libraries, government agencies, businesses, professional associations, and other nonprofit organizations were searched extensively via telephone, online, and in-person to locate data and statistics on the total number of libraries and librarians in firms, but the information could not be found (see Appendix C). The U.S. Department of Labor's U.S. Census Bureau (2006) reports projections for jobs and employment in the architectural and engineering industries, but it does not include librarians. To report revenue information, the government combines architecture with the engineering industry so it was not possible to glean any numbers from this data source. In the library profession, data on librarians is traditionally grouped in public, academic, school, special or 
corporate library categories. Furthermore, architectural design firm library information is grouped with special, corporate and art library literature and research (Primary Research Group, 2001). Research has been conducted on the total number of special, corporate and art libraries by professional associations, publishers, nonprofits, government agencies, but no data was located on the number of architectural design firm libraries or librarians. The American Library Association (ALA) reports on its Web site that there are currently 8,906 special libraries and they include corporate, medical, law, religious, etc., as comprising this category (ALA, 2009).

Jones and Gibson (1986) agree that the development of a professional association is the hallmark that art librarianship has arrived. At present, there are many professional associations that exist to serve the needs of art and academic architecture librarians, as well as special and corporate librarians. Architectural design firm librarians can be found listed in the membership rosters of the following library-related professional associations: Architecture Librarians Group (ARCLIB), Association of Architectural School Librarians (AASL), Association of Collegiate Schools of Architecture (ACLA), Art Libraries of North America (ARLIS/NA), and the ALA and SLA, to name a few. Two architectural librarian caucuses and sections are also currently active within SLA and ARLIS/NA. There are also more highly specialized professional associations that serve librarians and IM professionals managing or assisting with architectural design firm IM programs. Two of the more relevant and popular professional associations within the design firm community are the Resource Directors Association (RDA) and Visual Resource Association (VRA). 
A search for data and statistics was conducted in all library professional association and related websites (see Appendix D) and representatives for the associations were also contacted directly, but no data on the total number of architectural design firm librarians or libraries was located or reported to exist. The inclusion of architectural design firm librarians in membership listings and their presence on blogs and LISTSERVS in professional association environments that cater to the broader art library community certainly substantiates their existence, but their collective numbers are not known.

Directories (see Appendix E), indexes, books, journal articles, reports, and white papers were also searched for research, data, and statistics on the number of architecture firm libraries and librarians. There is inclusion in some of these sources in the form of listings submitted by design firms upon request from the publishers. SLA's (1999) Special Libraries and Information Centers lists a few architectural design firm libraries with the names and titles of the library contacts, but there is no data on their total numbers. The most useful data in list form is found in the Thomson Gale (2007) Directory of Special Libraries and Information Centers and it publishes the Contact, Title, Number of Staff, PH, Address, E-mail, Library Resources, and Web sites for over 25 architectural firm libraries and librarians. McGraw-Hill's "Top 500 Design Firms" list published in ENR magazine also generates an annual list of multidisciplinary design firms that are ranked based on revenue and coded based on architectural, engineering, landscape, interior, and other design services. ENR also compiles and provides the data for more highly specialized "Top 150 Architectural Design Firms" list (250 firms are 
actually ranked in the U.S.) that is based on reported revenue and published in Architectural Record $(A R)$ magazine.

\section{Research Studies on Architectural Libraries and Librarians}

The importance of continuing to research new special library populations is illustrated by the extensive effort of the SLA Illinois Chapter to conduct a study that included questionnaires and interviews to identify new special libraries and their services in the chapter area in the late 1970s. While no data were reported on architectural design firm libraries in the study, it set a precedent for research studies within the SLA community that has continued to this day.

A noteworthy corporate library study was also published by Matarazzo (1990) in conjunction with SLA whereby survey responses from senior corporate managers were analyzed to assess the characteristics and value of in-house library, librarians, and services. Matarazzo (1990) stated his motivation for publishing the case studies was to "capture the reasons for significant management support for the company library" (p. 1). Matarazzo stressed the importance of surveying the library users and decision makers in conjunction with the library managers. The intent of the survey research in this research study is not to determine the value of a corporate library. However, it sets the stage for more value-based research to be conducted in the future and for this reason, Mazzarro's (1990) study is included here to support research studies of that nature in the future.

Despite SLA's commitment to investigate new special library populations there is an apparent lack of existing and continuing research and literature focused on architectural design firm library practice. Pacey (1977) validated this fact, stating that 
research on design firm library work is relatively scarce. The earliest research on discovered on architecture libraries is by Schillaber (1954) who surveyed "libraries of all categories having collections in the field of architecture" (p. 1); however, the study was centered on public, historic, academic and museum collections and did not consider organizational systems and management. Schluntz (1974) later reported on academic architectural library collections and how well they cater to the educational needs of students. Schluntz (1974) surveyed 95 Association of California School Administrators (ACSA) members for the purpose of identifying "needed improvements" in architectural library services and made recommendations based on his findings.

In 1995, Shaw conducted a survey of 45 architectural and design firm librarians who were members of the AAL. Shaw's research identified the "diversity and scope" of architectural design firm libraries, and she reviews the available literature on the topic, as well as library services, collections, access, space, equipment, and library staff. She also considered the future of architectural design firm librarianship, in which her respondents' state relies on economic trends in the building and construction industry. Shaw (1995) also reported that "architectural librarianship in a corporate environment as a genre in library literature is still quite small" and goes on to say that during the course of her survey research she located only "a few articles" published between 1954 and 1994 that related to architectural design firm library work (p. 153).

In 2003, another survey was conducted by Craig with 163 librarians working in art and architecture libraries, and more specifically, academic and museum libraries in the U.S. and Canada. Based on the data collection, Craig identified "current, best practices 
in library instructional programs; library space; incorporation of digital image projects into collections; and changes to collection development and acquisitions due to the Internet" (pp. 92-93).

More recently, Dodd and Ball (2005) published a compensation survey that most closely resembles the topic of this study in that the titles, levels of education, and duties of art architecture and visual resource librarians are explored. The data were collected in 2004 for the main purpose of discovering compensation as it relates to duties performed; however, only $3.5 \%$ of the 469 respondents were from a U.S. corporate environment.

\section{Professional Sources Developed for Architectural Design Firm Library Managers}

Architectural design firm librarian, Kathleen Kalt, published two authoritative and highly applicable sources of information for architectural design firm library managers. While Kalt (1980) was employed by Skidmore, Owings and Merrill, she developed a guide on how to color code an architectural design firm library and it was published in Architectural Record magazine (p. 66). Kalt (1979) also created a lengthy manual for architectural library management and practice titled, Organizing and Managing Information in Architectural, Engineering and Consulting Firms, which Shaw (1995) referred to as the first effort to indentify and quantify library work in architectural design firm offices.

In the manual, Kalt (1979) stated that a "guide for those firms and individuals running an office library has been needed for some time" (Introduction). To meet that need, Kalt outlined key points that determine if a firm is ready for an in-house library and librarian and also described what a firm can expect a librarian to do. Kalt detailed her 
startup efforts and provides an organizational model for a library that includes (a) goals and objectives; (b) operations; (c) ordering procedures, cataloging, and classification; (d) manufacturers' literature, slides; (e) archives; (f) circulation; (g) reference work; and (h) in-house communication.

One of the key points Kalt (1979) stressed is that prior to the development of the in-house library, "vast amounts of time, money and materials were wasted through the lack of an effective central library to coordinate the acquisition and dissemination of information" (p. 2). Kalt's manual is a testament to a possible need for more highly relevant and comprehensive training materials to be developed for the librarians and $\mathrm{IM}$ professionals working in architectural design firm offices today.

Some other useful sources of reference generated in the library field and intended for use by for librarians and IM professionals working in art and architecture libraries are the ARLIS/NA AAT Advisory Committee's Art and Architecture Thesaurus which provides guidelines for cataloging and indexing visual and textual materials (ARLIS/NA, 2007), and Cataloging Architectural Drawings: A Guide to The Fields of RLIN (Ross, 1992). The J. Paul Getty trust has also generated the Art and Architecture Thesaurus Online (2009). ALA Editions has also produced ArtMARC Sourcebook: Cataloging Art, Architecture, and Their Visual Images (McRae and White, 1998) and Libraries Unlimited has published the Facilities Standards for Art Libraries and Visual Resources Collection (Irvine, 1991). 


\section{Other Literature about Architectural Design Firm Library Practice}

Books. Many books have been published on the subject of special and corporate libraries in the library field, but none are concentrated on architectural design firm library practice. Books categorized under "art libraries" provide the most closely related albeit slight and sporadic information. Some of the books that make mention of design firm libraries are Pacey's $(1977 ; 1985)$ Art Library Manual and Reader in Art Librarianship, Jones and Gibson's (1986) Art Libraries and Information Services, and Broxis's (1968) Organising the Arts. All of the aforementioned provide piecemeal information that can be applied to areas of architectural design firm library work, but the information must be extracted.

In addition, books categorized under engineering and architecture also produced some results about library work in design firm offices. Mount (1982) and Hamlin (1939) provided excellent time lines on the history of architects and engineers, as well as the academic, museum, and technical libraries that supported them over time. Mount's (1982) Ahead of its Time: The Engineering Societies Library 1913-80, and Conkling and Musser's (2001) Engineering Libraries: Building Collections and Delivering Services also offer historical context and organizational information that is useful, but the focus is on engineering libraries and providing for the information needs of engineers. Architects and engineers often work in the same office, however, so both sources make mention of organizational tools that serve the needs of architects, as well. Hamlin's (1939) The European Architectural Libraries: Their Methods, Equipment and Administration provides excellent historical perspective and general management and service 
information for architectural reference and research libraries, namely academic, government, and historical, but all of the environments in this source vary greatly from a corporate library structure, as well as it's IM systems and services.

Articles and Dissertations. Journal articles also provide some applicable literature on libraries and IM programs in the library field, but most of the information relating to an architecture firm "library" proper is outdated. Dissertations were also productive, however, searching and locating the work is a very time consuming task. Searches utilizing newer terms such as "information management," "knowledge management," "information technology" and "information systems" appear to produce better results for architecture firms and some of the more noteworthy are mentioned here.

Lohmann (1993) discussed Kalt's (1980) writings and their positive impact on architects' work. The author also reviewed and suggested categories of information resources and identifies the most desirable formats for architecture firms. Ballast (1990) argued that the field of architecture is information-based and newer technologies require that the industry continue to evolve by allocating time, money, and physical resources to develop better knowledge-based systems. Radonsky (1991), in her article on managing and organizing a firm library, discussed how to organize firm library resources and reference materials. Kanoglu and Arditi (2001) discussed computer-based information systems for architectural offices.

Two more current dissertations also provided useful and timely information. Protzen (1999) addressed managing technological changes in architectural practice. 
Barrow (2006) drew a correlation between better information technologies and having a competitive advantage in the field of architecture.

Conference Papers. The most current information in the library field on architectural design firm libraries is published by library-related professional associations such as the Art Libraries of North America (ARLIS) and the SLA in the form of conference papers. However, the majority of the literature is created for art libraries, and more specifically, visual resource collections in museums and historical collections. The most current and applicable information that is too lengthy to mention here (see Bibliography) can be found in the form of Occasional Papers and Conference Abstracts on the Art Libraries of North America (ARLIS) Web site, and also in the "Recent Industry Reports" and "Information Portals" on the SLA Web site. However, the information is designed to provide for the needs of art and special librarians so it is necessary to glean from the materials to derive any pertinent professional support.

\section{What the Literature Reveals About Architectural Design Firm Libraries}

Taken as a whole, the literature on architectural design firm libraries reveals some key characteristics about this emerging type of special library. Hamlin (1939), for example, was one of the first to note that an architecture library is "distinct in many respects because of different usage and the different nature of its collections" (p. 1). The architecture library often must harbor the old and integrate the new, resulting in the need to handle many different types and sizes of materials. Jones and Gibson (1986) commented on the digitization of collections, which is an expensive venture and, subsequently, a slow moving process. This implies there is will continue to be a need for 
physical space to harbor hard copy of resources until digital formats replace them, in addition to the newer digital information that have already been developed.

Architects and Librarians. Some of the literature discusses the employment of librarians and other IM professionals to manage architectural firm libraries and IM programs, resources and services. However, Ballast (1990) stated that architects have been serving as their firms' information specialists and utilized online databases and their own organizational systems to manage project information for easy retrieval. Schluntz's (1974) recommendation to "attempt to deliver the library resource to the practitioner" (p. 67) reaffirmed that the practitioner has been their own information manager in the past. This may imply that practitioners have also been actively pursued by academic architectural libraries to utilize their library services and, therefore, firm in-house library programs may not have been needed. However, despite having online access, the physical locations of architectural libraries may limit practitioner's ability to view materials on-site or to have them delivered. There was quite a bit of information located that was clearly intended for architects as the information managers. However, Ballast (1990) has suggested that the amount of information and complexity of the design process "has outrun architects' ability to keep up with it" (p. 39).

Libraries and IM Programs. Collections can vary greatly in size and scope, and the information needs in a design firm can vary depending on the industries they cater to, for example, hospitality, medical, government, or transportation, to name a few. Therefore, the level of training of the people in charge of the libraries and IM programs becomes important with regard to setting up and maintaining the technology and 
resources that must be focused on the industries the firm specializes in. Hamlin (1939) stated, "Every librarian of an architecture library is continually faced with problems that are the result of the specialized material within the library and the specialized functions it must fulfill" (Introduction).

The literature suggests that libraries and IM programs in architecture firms provide for the multidisciplinary information needs of end-users that may include: architects, engineers, interior designers, management, administrators, salespeople, as well as other employees. Design firm library practice may require the organization of the intellectual property generated by the firm, as well as the pooling of external information that contributes to the collective knowledge and creativity of the firm. It may be important for librarians and IM professionals to know how to successfully archive architectural drawings and presentations for easy retrieval. In addition, to make sure that local, state, and governmental regulations, as well as building and safety codes, are updated and accessible, can also be an integral part of the job. Technical papers and conference reports on, for example, scientific and technological advancements, energy efficiency, and sustainable green building, as well as clients' industry information, must be researched, captured and communicated. Finally, the acquisition, organization, and presentation of vendor information and materials samples are important components of design firm library service. Hamlin (1939) explained that architecture libraries' collections are "chosen to furnish inspiration to the designer, to guide and assist the layman, to enrich the historian of art, and to give the technician the materials he needs" (p. 1). 


\section{Summary}

The existence of several research studies published on architectural and design firm libraries by librarians suggests there is interest on the topic within the library field. However, the lack of statistics and data on this special library population suggests that there is a need for more evidence-based research in this population.

Much of the literature and other sources that were located provide scattered information that can be applied to facets of architectural design firm library practice, but most is difficult to find and outdated. The majority of the literature is also geared towards art libraries; more specifically, museum and nonprofit, and academic architectural libraries. However, these types of libraries have completely different hierarchies, sources for funding, and are typically nonprofit. The distinctions are illustrated by having different kinds of accountability procedures, as well as sets of rules and regulations that govern their existence. While some of the art library and academic architectural library literature on collection development, cataloging, and resources for the end-user, can be applied to a corporate program, it is being suggested here that design firm library management and practice have unique needs with regard to the type of resources needed for the end-users and how the resources are purchased, as well as how they are integrated into the firm and shared with the firm management, employees, and clients.

Architectural design firm library practice is specialized in the same way medical and law libraries are, and, therefore, professional support materials that more closely address the multifaceted nature of the libraries and IM programs in these offices would be 
of value. More applicable, up-to-date, and comprehensive training manuals or guides that meet the varied needs of the librarians and IM professionals in charge of managing and assisting with the resources and services might also be in order. 


\section{Chapter 3}

\section{Methodology}

Qualitative and quantitative research methods were utilized to collect and analyze data. The sample population, tools, data collection tools, and limitations of the research are discussed here. This research was not deduced from theory, but rather, grounded in actual observations. The lack of current data and research on design firm libraries and librarians was the primary reason to conduct this exploratory study.

\section{Sample Population}

In 1998, SLA identified that firms with higher rankings on the "Fortune 500" list were "significantly more likely than those ranked lower to have a corporate library or information center" (SLA, 1998, para. 1). Based the fact that Fortune 500 companies are measured by gross revenue, and in lieu of any comprehensive data existing on the number of architectural design firm libraries and librarians, it seems fitting for the purpose of this study to survey architecture firms ranked by revenue. Therefore, the criteria by which firms were selected for inclusion in the survey population was based on their inclusion in Architectural Record's (AR) "Top 150 Architecture Firms" list. An additional 100 firms are also ranked for a total of 250 on the list. The $A R$ list is compiled by McGraw-Hill "on the basis of reported revenue derived from architectural services only" in 2008 ( $A R, 2006$, p. 42).

Firm receptionists at the 250 firm offices on the $A R$ list were called and those that were contacted directly were asked if an in-house "library" existed, and if so, if a "librarian" was employed to administer or assist with programs. If a "librarian" was not 
identified, the receptionist was asked if one professional was "in charge" of managing or assisting with the library. Contact names, job titles, programs, and e-mail addresses were verified and participation in the study was elicited by speaking directly with the librarian or IM professional. If it was not possible to reach a person identified as in charge or assisting with a library or IM program, then the name(s) and number of programs reported by the receptionist was recorded. The use of the $A R$ list provided a sample population of employed in-house IM professionals that administered or assisted with IM programs. The process by which this sample was identified is described in further detail in Chapter 4. The IM professionals surveyed are suggested to be generalizable to a population of architecture firms that denote an ability to support a library program and dedicate a professional to manage or assist with administering the resources and services.

The 25 firms reported to employ IM professionals that are listed under "Architecture" in the Thomson Gale (2007) Directory of Special Libraries and Information Centers were also cross-referenced with the 250 firms on the $A R$ list to see if they are present in both sources. In addition, to see if there is any discrepancy between firms known to employ librarians and IM professionals listed in the directory and the number of librarians and IM professionals discovered to be working in the firms that are on the $A R$ list. The data is presented in further detail in Chapter 4.

\section{Data Collection}

Firm receptionists and IM professionals were contacted by telephone during the phone inquiry stage to acquire data on the number of libraries or IM programs, and librarians and IM professionals, in the firms on the $A R$ list, and to also derive a sample 
population to survey (see Appendix G). The IM professionals who agreed to participate in the study were then contacted via an e-mail message that housed a cover letter detailing informed consent and a link to Survey Monkey ${ }^{\mathrm{TM}}$, the web-based survey questionnaire (see Appendix H). The survey questionnaire collected data about the IM programs and IM professionals in the sample population. Follow-up e-mails were sent on a weekly basis to all survey participants that had not completed the survey. E-mail was also utilized to send a thank you to all of the survey participants who completed the survey, and will be used to send the results of this research study after it has been approved.

\section{Use of E-mail as Data Collection Tool}

It is reported that "e-mail enables researchers to cost-effectively and concurrently study individuals or groups with special characteristics or those often difficult or impossible to reach such as executives or those who are geographically dispersed" (Meho \& Tibbo, 2003, para. 34). In addition, "people perceive online communication as anonymous because there is no in-person contact and thus little accountability. Research has shown that embedded links result in significantly higher response rates (five times as much) than do those attached as an e-mail message (Dommeyer \& Moriarty, 2000). Meho and Tibbo (2003) report there are high rates of nondelivery due to changes in e-mail addresses, information overload, and the fact that messages are often deleted before they are read. However, "e-mail survey reminders can significantly increase participation rates" (Meho \& Tibbo, 2003, para. 37). 


\section{Survey Instrument}

The survey questionnaire (see Appendix F) was created using the online survey tool Survey Monkey ${ }^{\mathrm{TM}}$ and that served as a data gathering instrument. The survey questions were created based on information gathered in the literature review, and feedback from the survey pretest group and thesis committee members. The survey questions included multiple-choice, fixed-response, and open-ended questions, as well as combinations thereof. The survey questions can be viewed in their entirety in Appendix F.

The survey questions were specifically designed to collect information for the following research questions:

1. What kinds of libraries and IM programs exist in U.S. architectural design firm offices and what types of resources and services do they provide? Q4 and Q5 identify IM programs in the office by name. Q8 specifies tools and resources that are the responsibility of the library or IM program. Q13 identifies if there is a budget. Q14 requests length of time the library or program has existed. Q15 determines square footage dedicated to the professional and program resources. Q16 determines how are resources and information is delivered to the end users. Q17 identifies how many people utilize resources or services. Q18 specifies how active the end users are by group. Q19 determines the primary information needs of end users by discipline or department.

2. Who is in charge of managing or assisting with the libraries or IM programs in U.S. architectural design firm offices and what are their job responsibilities? Q1, Q2, and Q3 specify job titles and levels of education, and, more specifically, if the professional 
has a library science degree. Q6 and Q7 determine the number of people who dedicate time and are paid to work with library or IM program. Q9 and Q10 identify job duties and job responsibilities. Q20 asks how the information needs of end-users are determined. Q21 inquires if the value of the programs, resources or services are evaluated or measured in any way. Q22 investigates the communication tools utilized to convey information about resources and services.

3. Do the professionals who manage or assist with the libraries and IM programs perceive the existing professional literature, training materials and other sources as sufficient in supporting their ability to administer their programs' resources and services? Q11, Q 11b, and Q 12 request that professionals rank professional sources in order of how helpful they are in supporting them in their ability to administer their programs, and also specify if they perceive the existing professional literature, sources, and other materials as sufficient in supporting them in their ability to administer their programs, resources and service. If not, the respondents were asked to specify what they would like to see developed. Q23 identifies the professional associations the respondents have joined to support them in their IM work.

\section{Survey Pretest}

The cover letter and survey questions were pretested via e-mail with three IM professionals that were randomly selected from the Thomson Gale (2007) Directory of Special Libraries and Information Centers. Based on their responses and feedback the survey cover letter and survey questions were revised, and the survey questionnaire was restructured. 


\section{Data Analysis}

The analysis of the data collected in this study is purely exploratory in the sense that no relationships between variables, or differences between groups, were either predicted or evaluated. Thus, for the survey responses, the analytic methods are at a descriptive level indicating relative frequencies and percentages of response categories for questions with categorical response categories and means and standard deviations for questions with scaled response categories. Since the number of categories in the scales used in this study was small, it was also convenient to provide the frequency distributions across the scale categories.

More specifically, nonusable data (responses that were not clear, and survey questions that were not completed) were eliminated. The raw data from the multiple choice and open-ended questions were coded with an identifying letter and detailed according to the responses for each question. Responses from open-ended responses and any "Other-Please Specify" responses were qualitatively interpreted. Descriptive answers were coded into an "Other" category and factored as such. This data collection method reflects a composite measure of total number of responses to each survey question.

\section{Limitations of the Research}

The primary limitation of this research is that design firms that are not ranked in the $A R$ list are excluded. Additionally, despite the fact that this research study may reveal a desire for more applicable professional training materials for the administrators and assistants working with libraries and IM program resources and services, the population 
identifying needs may not financially support them. Another data collection limitation may include flaws in the survey questions including lack of necessary options to select from which resulted in skipped questions. However, the researcher tried to minimize these limitations by pretesting and revising the survey questionnaire. Although every effort was made to ensure accurate data collection, computational errors, recording errors, and coding errors may have also skewed the validity of the results. Open-ended questions and "Other-Please Specify" comments were also difficult to quantitatively interpret and, therefore, are presented in list form in the tables and summaries and/or grouped together to represent a collective percentage of number of respondents for each question. 


\section{Chapter 4}

\section{Results}

\section{Phone Inquiry}

The 250 architecture firms that are ranked on the $A R$ list were contacted by phone and 218 or $87.2 \%$ of the firm receptionists verified the firm office had one or more libraries or IM programs by another name. Eleven firms have no libraries or IM programs or IM professionals. No data are available on the remaining 21 firms that were out of business or had voice mail systems in lieu of a receptionist.

Table 1

Library and Information Management Programs Reported in Architecture Firm Sample

\begin{tabular}{lcc}
\hline \multicolumn{1}{c}{$A R$ Firms } & Number & Percent \\
\hline Firms with one or more libraries or IM programs & 218 & 87.2 \\
Firms without libraries or IM programs & 11 & 4.4 \\
No data available & 21 & 8.4 \\
Total & 250 & 100 \\
\hline
\end{tabular}

One hundred and eighty-seven or $74.8 \%$ of the firms specified one or more IM professionals managing or assisting with the libraries or IM programs. Of the 187 firms that reported having librarians or IM professionals, 95 librarians and IM professionals were contacted over the course of the 3-month phone-calling period and their professional status and programs were verified. Out of the 95 professionals that were reached, 88 agreed to participate in this survey research. Sixty-eight of those that agreed to participate actually completed the survey questionnaire. This number of completed 
surveys represents a $77.3 \%$ response rate within the final sample of those who agreed to participate, and a $36.4 \%$ of the total sampling frame.

Table 2

Librarians and Information Management Professionals Reported in Firms Ranked on Architectural Record List

\begin{tabular}{lcc}
\multicolumn{1}{c}{$A R$ firms } & Number & Percent \\
\hline $\begin{array}{l}\text { Total number of firms reporting one or more librarian or } \\
\text { IM professional }\end{array}$ & 187 & 74.8 \\
$\begin{array}{l}\text { Number of firms with a librarian or IM professional who } \\
\text { could not be contacted }\end{array}$ & 99 & 53 \\
$\begin{array}{l}\text { Number of firms in which a librarian or IM professional } \\
\text { was contacted }\end{array}$ & 95 & 51 \\
$\begin{array}{l}\text { Number of firms in which a librarian or IM professional } \\
\text { agreed to complete survey }\end{array}$ & 88 & 47 \\
$\begin{array}{l}\text { Number of firms in which a librarian or IM professional } \\
\text { completed survey }\end{array}$ & 68 & 36.4 \\
\hline
\end{tabular}

Other discoveries made through the phone inquiry phase were that only 13 of the 25 firms listed in the Thomson Gale Directory of Special Libraries and Information Centers are ranked in the $A R$ list. This suggests that there are more firms outside of the 250 ranked by revenue in the $A R$ list that support IM programs and employ IM professionals, but total number of additional firms in the U.S. is undetermined.

Also, 6 out of the 187 librarians and IM professionals that were identified stated they are employed by the $A R$ firms as outside consultants to manage the firm library or IM program. All 6 work for more than one firm, but they did not specify whether the other firms ranked on the $A R$ list or not. Two agreed to participate in this survey research 
and to represent one firm on the $A R$ list, and the remaining four declined stating that participating in this research study might breech their confidentiality agreements.

\section{Survey Responses}

Out of the 187 librarians and IM professionals that were identified in the phone inquiry stage, 95 were contacted directly, and 88 agreed to participate in this research study. Sixty-eight respondents completed the survey questionnaire which was made available online for 8 weeks through the services of Survey Monkey ${ }^{\mathrm{TM}}$. In this chapter, the responses to each question are summarized in the form of frequency distributions and percentages over the response categories. Responses to each question are summarized in terms of the most prevalent response categories and all of the data is reported in the charts. For several questions, extensive use of the "Other" category allowed participants to write in responses that were not available among the provided options or that they felt conveyed additional needed details. All such responses were categorized according to the following rules:

1. If a response was just a more specific example of an existing alternative (e.g, "materials" library instead of choosing the existing "library" alternative), it was counted under the existing category.

2. A new category was created if it was specified by 2 or more respondents.

3. All write-in responses that occurred only once were counted under the "Other" category.

4. The survey question responses are shown in the tables in the order in which they appear in the survey. 
Question 1: What is your primary job title? If you have more than one title, please list them in the rows provided.

Table 3

Frequencies of Primary, Secondary, and Tertiary Job Titles Held by Survey Respondents

\begin{tabular}{|c|c|c|c|}
\hline & Primary job & Secondary job & Tertiary job \\
\hline Job title & $\begin{array}{c}\text { Number of } \\
\text { responses }\end{array}$ & $\begin{array}{c}\text { Number } \\
\text { of responses }\end{array}$ & $\begin{array}{c}\text { Number of } \\
\text { responses }\end{array}$ \\
\hline Administrative assistant & 4 & & \\
\hline Architect & 3 & & \\
\hline Archivist & & 2 & \\
\hline Architectural designer & 1 & & \\
\hline Architecture librarian & & & 1 \\
\hline Architectural resource librarian & 1 & & \\
\hline Assistant to the president & 1 & & \\
\hline Associate principal & 1 & 1 & \\
\hline Associate/administrative assistant & 1 & & \\
\hline Cad designer & 1 & & \\
\hline Corporate library manager & 1 & & \\
\hline Designer & & 1 & \\
\hline Director of interiors & 1 & & \\
\hline Director of specifications & & 1 & \\
\hline Head designer & 1 & & \\
\hline HR contact & & 1 & \\
\hline Information manager & 1 & & \\
\hline Information specialist & 1 & & \\
\hline Interior designer & 11 & 1 & 1 \\
\hline Interior librarian & & 1 & \\
\hline Interiors administrator & 1 & & \\
\hline Intern architect & 3 & & \\
\hline Job captain & & 1 & \\
\hline Librarian & 9 & 2 & 2 \\
\hline Library \& information specialist & 1 & & \\
\hline
\end{tabular}


Table 3 (continued)

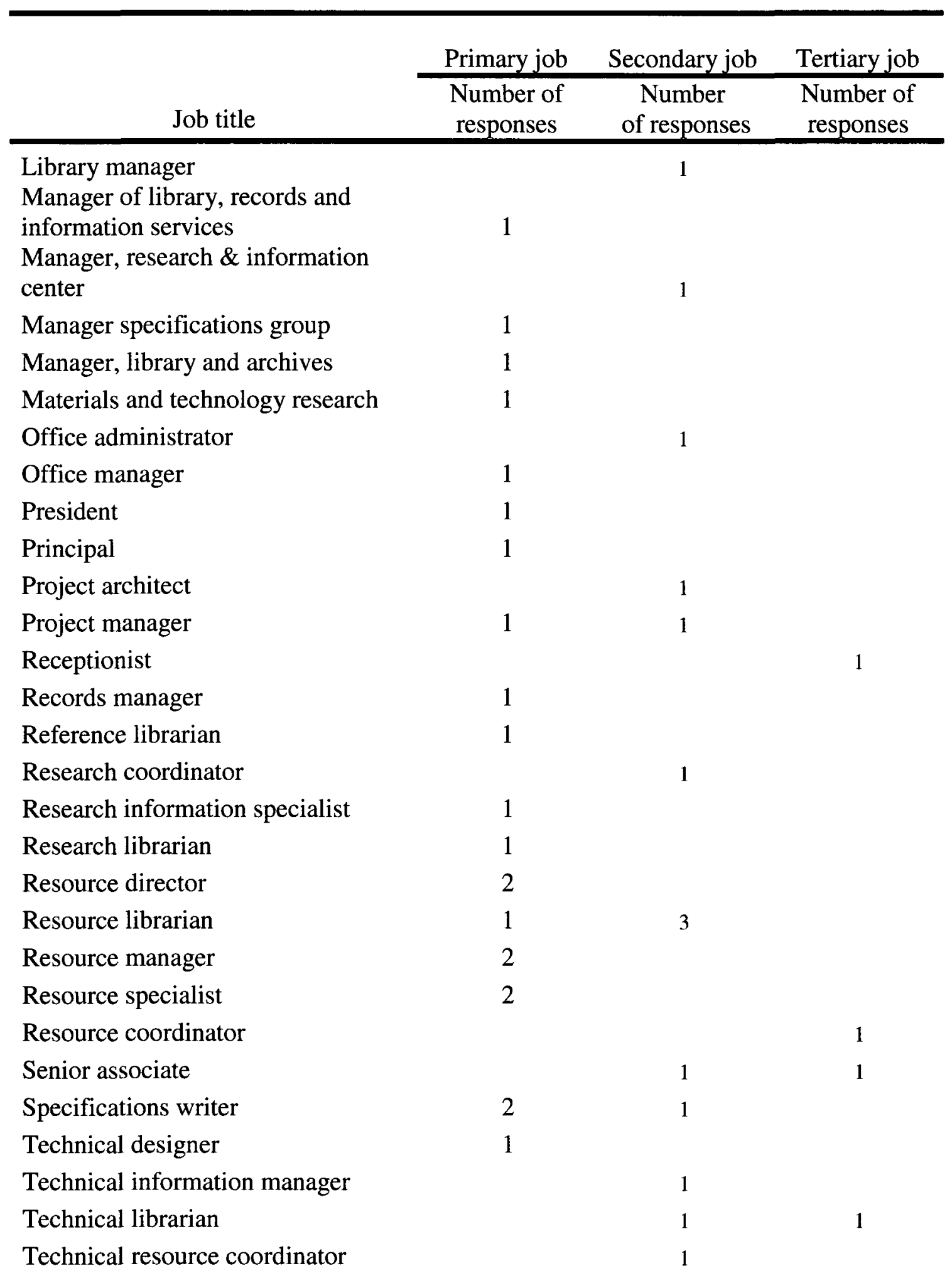


Table 3 (continued)

\begin{tabular}{lccc}
\hline & Primary job & Secondary job & Tertiary job \\
\cline { 2 - 4 } \multicolumn{1}{c}{ Job title } & $\begin{array}{c}\text { Number of } \\
\text { responses }\end{array}$ & $\begin{array}{c}\text { Number } \\
\text { of responses }\end{array}$ & $\begin{array}{c}\text { Number of } \\
\text { responses }\end{array}$ \\
\hline Technical resources specialist & 1 & & \\
Technical services assistant & 1 & & \\
Vice president & 1 & & \\
\hline
\end{tabular}

Respondents were given the opportunity to enter up to three different job titles they held. Twenty-nine of the 68 respondents (43\%) indicated that at least one of their job titles is librarian, library manager or manager of a "library." Another 16 respondents or $24 \%$ specified job titles that are well within the scope of library or IM work. Forty-five or $67 \%$ of those who responded appear to represent professionals with library or some type of IM designation as their primary, secondary and tertiary job titles. The remaining 3 or $34 \%$ represent professionals with titles that suggest the library and IM role is not their primary focus. In addition, 33 of the 68 respondents (49\%) reported having secondary and tertiary job titles. The best way to summarize the primary, secondary, and tertiary job titles reported is in tabular form, as shown above.

Question 2: What is your highest level of education? 
Table 4

Frequency Distribution of Education Level of Survey Respondents

\begin{tabular}{lcc}
\hline \multicolumn{1}{c}{ Level of education } & $\begin{array}{c}\text { Number } \\
\text { responding }\end{array}$ & $\begin{array}{c}\text { Percent of } \\
\text { respondents }\end{array}$ \\
\hline Associate's degree & 6 & 8.8 \\
Bachelor's degree & 38 & 55.9 \\
Master's degree & 21 & 30.9 \\
Doctorate & 0 & 0.0 \\
None of the above & 3 & 4.4 \\
Total & 68 & 100 \\
\hline
\end{tabular}

The majority of respondents at 30 or $55.9 \%$ report having their bachelor's degree.

The next most frequent level is having a master's degree, which is reported by 21 or $30.9 \%$ of the respondents. Associate degrees are held by $8.8 \%$ of the subjects. The 3 remaining or final $4.4 \%$ of those that answered selected "None of the above."

Question 3: Please select one of the following:

Table 5

Frequency Distribution of Library Science Degrees Among Survey Respondents

\begin{tabular}{lcc}
\hline \multicolumn{1}{c}{ Answer options } & $\begin{array}{c}\text { Number } \\
\text { responding }\end{array}$ & $\begin{array}{c}\text { Percent of } \\
\text { respondents }\end{array}$ \\
\hline I have a Library Science degree & 17 & 25.0 \\
I am working on a Library Science degree & 0 & 0.0 \\
None of the above & 51 & 75.0 \\
Total & 68 & 100 \\
\hline
\end{tabular}

One quarter of the subjects reported having degrees in Library Science. The remaining $75 \%$ indicated they do not have, and are not working on, a Library Science degree. 
Question 4: Select the actual name, if any, of the information management program(s), department(s) or center(s) that you manage or assist with:

Note: If the name(s) differ(s) in any way from those listed (or is a combination thereof, for example, Resource Materials Library) then ONLY select "Other Names(s)" and specify the name(s) in the space provided.

Table 6

Frequency Distribution of Names of Survey Respondents' Information Management $\operatorname{Program}(s)$

\begin{tabular}{llc} 
Answer options & $\begin{array}{c}\text { Number } \\
\text { responding }\end{array}$ & $\begin{array}{c}\text { Percent of } \\
\text { respondents }\end{array}$ \\
\hline
\end{tabular}

I manage or assist with resources and/or services

only. There is no program, department or center

by any name.

Library ${ }^{A}$

Archives department ${ }^{\mathrm{B}}$

Records department

Information center ${ }^{\mathrm{C}}$

Materials center

Resource center $^{\mathrm{D}}$ responding respondents

Knowledge center

Other name(s) ${ }^{\mathrm{E}}$

Total number of respondents

$\begin{array}{cc}9 & 13.2 \\ 55 & 80.9 \\ 7 & 10.3 \\ 4 & 5.9 \\ 5 & 7.4 \\ 12 & 17.6 \\ 12 & 17.6 \\ 0 & 0.0 \\ 30 & 44.1 \\ 68 & 100.0\end{array}$

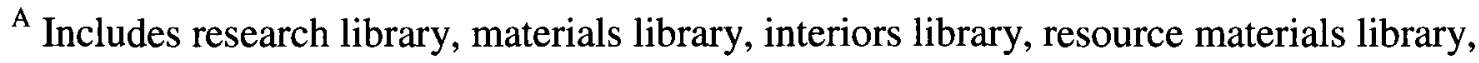
product library, architectural library, specifications technical library, electrical library, structural library, sample library, interior finish library, technical resource library, main architectural product library, main library, departmental vendor library, design library, architectural materials library.

${ }^{B}$ Includes archives, records, and information.

C Includes information center, research \& information center, information resource center.

${ }^{D}$ Includes resource center, architectural resource center.

${ }^{\mathrm{E}}$ Includes new materials and technologies (samples \& information), interior furniture \& finishes (catalogs \& samples), technical services department. 
The number of responses shows that many of the respondents manage or assist with two or more programs in the firm office. The 68 respondents specified 125 names. However, it is also possible that participants selected an option and also specified a name in the "Other name" space provided. Percentages were factored grouping names from the "Other name" category with other options that had common derivatives. All of the "Other names" that were specified by repondents are coded from A, B, C, D and E above.

By far, the most common name for IM programs in these organizations includes the term "library;" nearly $81 \%$ of respondents reported this. In most cases this term is modified by descriptors, such as architectural, research, product, materials, interiors, vendor, design, resource materials, architectural materials, specifications, technical, structural, samples, interior finishes, technical resource, or main. The next most common names for the programs are "materials center" and "resource center," each mentioned by $17.6 \%$ of the respondents. Nine of the 68 respondents reported that they provide only resources and services and there is no program by any name.

Question 5: Select all other information management programs, departments or centers that exist in your office that you DO NOT manage or assist with: 
Table 7

Frequency Distribution of Names of Other Information Management Programs in Survey Respondents' Offices

\begin{tabular}{lcc}
\hline \multicolumn{1}{c}{ Answer options } & $\begin{array}{c}\text { Number } \\
\text { responding }\end{array}$ & $\begin{array}{c}\text { Percent of } \\
\text { Respondents }\end{array}$ \\
\hline Library $^{\text {A }}$ & 14 & 28.0 \\
Archives department $^{\mathrm{b}}$ & 26 & 52.0 \\
Records department $_{\text {Information center }}$ & 19 & 38.0 \\
Materials center $^{\mathrm{c}}$ & 8 & 16.0 \\
Resource center $_{\text {Knowledge center }}$ & 12 & 24.0 \\
Other name(s) & 9 & 18.0 \\
Total answered question & 7 & 14.0 \\
Unanswered & 12 & 24.0 \\
Total participants & 50 & 73.5 \\
\hline
\end{tabular}

${ }^{A}$ Includes resource library, materials library, interiors library, samples library, dept. library, architectural library, design library, codes library, architectural resources library, submittal and spec library, architecture library, legal library, image library.

B Includes archive, archives, archiving program.

${ }^{\mathrm{C}}$ Includes materials center, materials center (design samples).

D Includes archivist, materials librarian, interior materials, IT, IM, consultant, engineering technical resources, catalog, specifications dept., database, images collection, Intranet, standard details.

This question was answered by distinctly fewer participants (73.5\%). Most commonly mentioned are library, archives department, records department, and materials center. This may suggest that a "None of the above" option may have been useful to include to discover the total number of programs that exist in the respondents' offices. 
Question 6: What is the total number of full and/or part-time people (including yourself) in your office that dedicate paid time to your information management program(s), resources or services?

Table 8

Frequency Distribution of Staffing Levels For Survey Respondents' Information Management Program(s)

\begin{tabular}{lcc}
\hline \multicolumn{1}{c}{ Answer options } & $\begin{array}{c}\text { Number } \\
\text { responding }\end{array}$ & $\begin{array}{c}\text { Percent of } \\
\text { respondents }\end{array}$ \\
\hline One (me) & 24 & 36.9 \\
2-3 (myself and others) & 31 & 47.7 \\
4-5 (myself and others) & 5 & 7.7 \\
6-7 (myself and others) & 1 & 1.5 \\
8-9 (myself and others) & 2 & 3.1 \\
10 or More (myself and others) & 2 & 3.1 \\
Total answered question & 65 & 95.6 \\
Unanswered & 3 & 4.4 \\
Total participants & 68 & 100.0 \\
\hline
\end{tabular}

The most prevalent number of people dedicated to managing or assisting with the libraries and IM programs in the firm offices is 2 to 3 people (reported by $47.7 \%$ of those responding). Not far behind this response (36.9\%) is that only one person is assigned to the IM program. Higher numbers of personnel assigned to programs (i.e., from 4 or more) are reported by a total of 10 respondents.

Question 7: Approximately how much paid time TOTAL PER WEEK do all full and part-time people (including yourself) dedicate to your information management program(s), resources or the services you provide? 
Table 9

Frequency Distribution of Paid Time Per Week For Staff of Information Management $\operatorname{Program}(s)$

\begin{tabular}{lcc}
\hline \multicolumn{1}{c}{ Answer options } & $\begin{array}{c}\text { Number } \\
\text { responding }\end{array}$ & $\begin{array}{c}\text { Percent of } \\
\text { respondents }\end{array}$ \\
\hline 4 hours or less (myself plus others) & 18 & 28.1 \\
4.5 up to 8 (myself plus others) & 12 & 18.8 \\
8.5 up to 12 (myself plus others) & 0 & 0.0 \\
12.5 up to 16 (myself plus others) & 2 & 3.1 \\
16.5 up to 20 (myself plus others) & 4 & 6.3 \\
20.5 up to 24 (myself plus others) & 1 & 1.6 \\
24.5 up to 28 (myself plus others) & 4 & 6.3 \\
28.5 up to 32 (myself plus others) & 3 & 4.7 \\
32.5 up to 40 (myself and all others) & 10 & 15.6 \\
More than 40 hours (myself plus others) & 10 & 15.6 \\
Total answered question & 64 & 94.1 \\
Unanswered & 4 & 5.9 \\
Total participants & 68 & 100.0 \\
\hline
\end{tabular}

Responses to this question followed a "U" distribution. Almost $47 \%$ of the respondents indicated that very low numbers of hours per week (i.e., 8 or less) are devoted to the IM program. At the other extreme, $31.2 \%$ of the respondents reported that 32.5 or more hours are spent on this function. None of the four middle-range numbers of hours were selected by more than $6.3 \%$ of the respondents. It can be inferred that the firms represented here engage in either extensive use of their programs, resources and services or very little use, with few falling in the middle range.

Question 8: Select only the following tools and resources that are a responsibility of your information management program(s): (Select all that apply) 
Table 10

Frequency Distribution of Tools and Resources Utilized in Survey Respondents'

Information Management Program(s)

\begin{tabular}{|c|c|c|}
\hline Answer options & $\begin{array}{l}\text { Number } \\
\text { responding }\end{array}$ & $\begin{array}{l}\text { Percent of } \\
\text { respondents }\end{array}$ \\
\hline Drawing or plans & 13 & 19.7 \\
\hline Building and safety code information ${ }^{A}$ & 42 & 63.6 \\
\hline Materials samples & 53 & 80.3 \\
\hline Vendor catalogs & 60 & 90.9 \\
\hline Books ${ }^{\text {B }}$ & 53 & 80.3 \\
\hline Journals, magazines, newsletters or newspapers & 51 & 77.3 \\
\hline Exhibition or museum catalogs & 4 & 6.1 \\
\hline Subscription databases & 22 & 33.3 \\
\hline Professional association memberships & 15 & 22.7 \\
\hline Microforms & 3 & 4.5 \\
\hline Slides & 2 & 3.0 \\
\hline Digital images or photographs ${ }^{\mathrm{C}}$ & 12 & 18.2 \\
\hline $\begin{array}{l}\text { Company Web site (design, development, } \\
\text { maintenance) }\end{array}$ & 3 & 4.5 \\
\hline Business or job records & 7 & 10.6 \\
\hline Legal or government documents & 5 & 7.7 \\
\hline Internet (access) & 8 & 12.1 \\
\hline $\begin{array}{l}\text { Intranet (your firm's internal computer } \\
\text { communication network) }{ }^{\mathrm{D}}\end{array}$ & 15 & 22.7 \\
\hline $\begin{array}{l}\text { Extranet (your firm's shared Intranet network to } \\
\text { outside organizations) }\end{array}$ & 1 & 1.5 \\
\hline Equipment such as copiers, projectors, or computers & 5 & 7.7 \\
\hline Other ${ }^{\mathrm{E}}$ & 15 & 22.7 \\
\hline Total answered question & 66 & 97.1 \\
\hline Unanswered & 2 & 2.9 \\
\hline Total participants & 68 & 100.0 \\
\hline
\end{tabular}

A Includes building and safety code information, building codes \& standards, building standards \& cost estimating guides.

B Includes books, project concept design books.

C Includes digital images or photographs, digital resource folders.

${ }^{D}$ Includes two sites within corporate Intranet: a Research Library Blog/Wiki site and a more formal Research Library Catalog site, managing/editing Intranet, Intranet blog. 
Table 10 (continued)

${ }^{\mathrm{E}}$ Includes professional standards \& handbooks, specifications system updates (Web site accessible), maps-internal databases, maps, product literature binders, vendor show \& tells, lunches \& learns, in-house vendor presentations, and EOS.

The following five categories of resources define the primary tools and resources of the IM programs in a sizeable majority of the firms participating in this survey: (a) building and safety code information; (b) materials samples; (c) vendor catalogs; (d) books; and (e) journals, magazines, newsletters or newspapers. Although each of the other 15 categories of materials is mentioned by 1 to 15 respondents, none of these approached the average frequency of mention (i.e., 51.8) of those listed above.

Question 9: Select the following job duties that are necessary functions of your information management program(s) or work: (Check all that apply) 
Table 11

Frequency Distribution of Survey Respondents' Information Management Job Duties

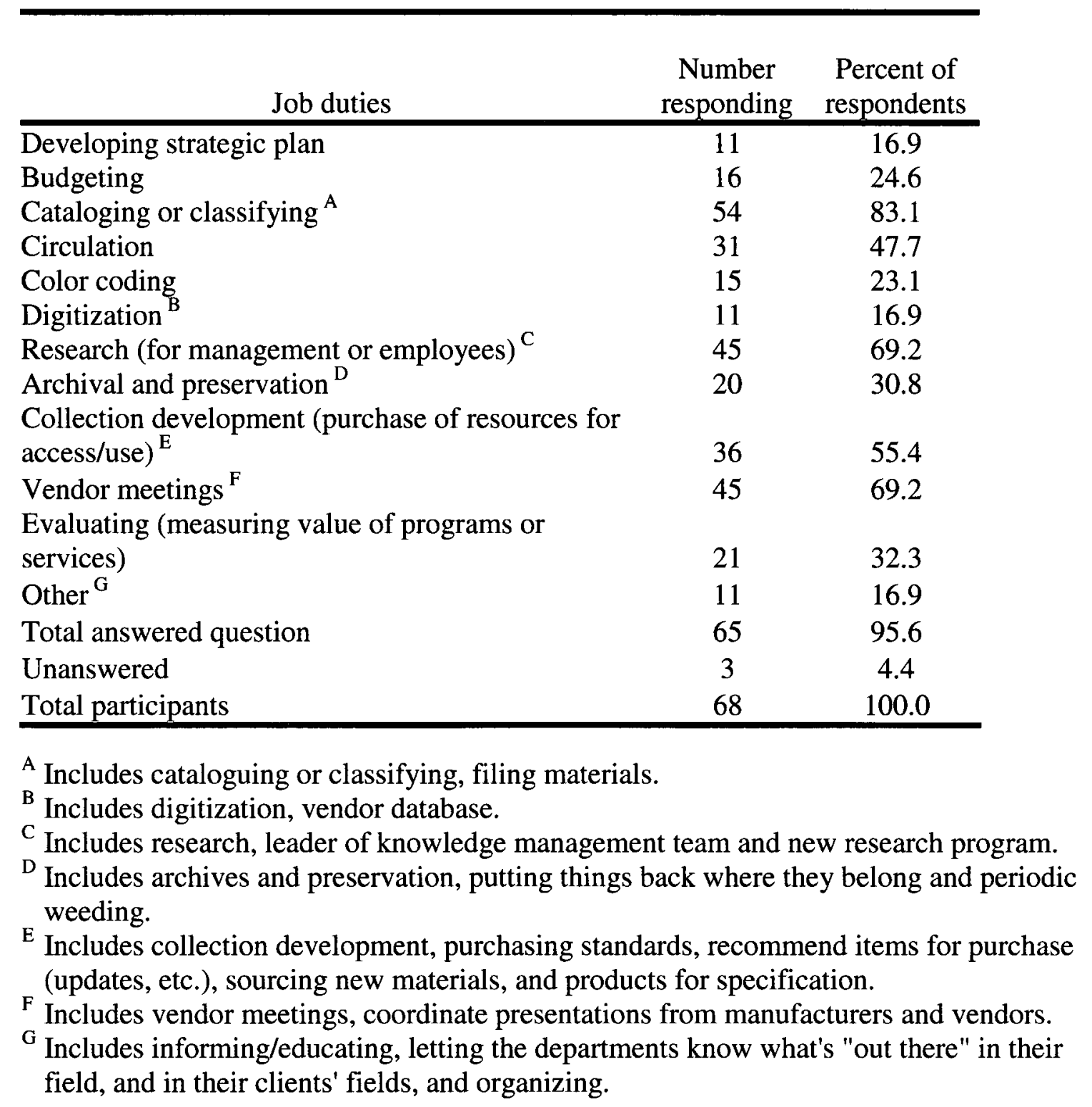

Respondents indicate that their necessary functions are primarily: cataloging or classifying, circulation, research (for management and employees), collection development, and vendor meetings. Fifteen to twenty percent of the respondents indicated that they are also involved in more technical activities, such as color coding, 
digitization, and archival preservation. The "Other" responses included researching and communicating what's happening in the end-user group's field, and their clients' fields, as well as organizing information.

Question 10: Select only the following that are expected to be administered to all of your firm's offices nationwide as part of your information management program(s) or work:

Table 12

Frequency Distribution of Functions of Survey Respondents' Information Management $\operatorname{Program}(s)$

\begin{tabular}{lcc}
\hline \multicolumn{1}{c}{ IM program functions } & $\begin{array}{c}\text { Number } \\
\text { responding }\end{array}$ & $\begin{array}{c}\text { Percent of } \\
\text { respondents }\end{array}$ \\
\hline Library catalog & 30 & 53.6 \\
Drawing or plans & 8 & 14.3 \\
Digital Images or photographs & 9 & 16.1 \\
Vendor information & 33 & 58.9 \\
Building and safety code information & 30 & 53.7 \\
Subscription databases ${ }^{\text {a }}$ & 25 & 44.6 \\
Professional association memberships/information & 12 & 21.4 \\
Book purchases & 22 & 39.3 \\
Journal/magazine/newsletter/newspaper & & \\
Subscriptions (online or hard copy) & 22 & 39.3 \\
Intranet $^{\text {B }}$ & 17 & 30.4 \\
Extranet & 2 & 3.6 \\
Company Web site & 4 & 7.1 \\
Business or job records & 5 & 8.9 \\
Other firm databases ${ }^{\text {C }}$ & 3 & 5.4 \\
Other D & 2 & 3.6 \\
Total answered question & 56 & 82.4 \\
Unanswered $_{\text {Total participants }}$ & 12 & 17.6 \\
\hline
\end{tabular}

A Includes subscription databases, search and retrieve data from ASTM databases and other internet-based databases. 
Table 12 (continued)

${ }^{\mathrm{B}}$ Includes intranet, maintain intranet blog.

${ }^{\mathrm{C}}$ Includes maintain in-house databases, including product and project databases.

${ }^{\mathrm{D}}$ Includes maintaining and utilizing Master Specification System, maintain technical resource folders.

Between one third and one half of those responding indicated that they provide the library catalog, vendor information, building and safety code information, subscription databases, journal, magazine, newsletter, newspaper subscriptions, and book purchasing functions for the firm nationwide, rather than solely for their own office. All of the remaining resources (drawings and plans, digital images, or photographs, professional association information, subscriptions [online and hard copy], Intranet, Extranet, company Web site, business or job records, other firm databases, and "Other" resources such as Master Specification System and technical resource folders), are administered primarily for on-site usage.

Question 11: Do you feel the existing professional literature, training materials and other sources are sufficient to support your ability to manage or assist with your information management program(s) or work? 
Table 13

Frequency Distribution of Survey Respondents' Perceptions of Professional Support

Materials For Information Management Professionals in Architecture Firms

\begin{tabular}{lcc}
\hline \multicolumn{1}{c}{ Answer options } & $\begin{array}{c}\text { Number } \\
\text { responding }\end{array}$ & $\begin{array}{c}\text { Percent of } \\
\text { respondents }\end{array}$ \\
\hline Yes & 22 & 33.3 \\
No & 22 & 33.3 \\
Do not know & 22 & 33.3 \\
Total answered question & 66 & 97.1 \\
Unanswered & 2 & 2.9 \\
Total participants & 68 & 100.0 \\
\hline
\end{tabular}

The distribution of responses to this question is quite unusual in that each of the three options (i.e., Yes, No, Do not know) received one third of the answers. If the "Do not know" group is factored in with the "No" group then it would be safe to infer that only a minority hold the view that the professional literature, training materials and other sources are sufficient to support them in their IM work.

Question 11a: What professional literature, training materials or other sources would you like to see developed to better support your ability to administer or assist with your information management program(s) or work? 
Table 14

Professional Support Materials Survey Respondents' Would Like to See Developed For

Information Management Professionals in Architecture Firms

Desired support materials

When I started, I would have liked an electronic or print resource that addressed the basic, crucial books and magazines that all architectural firms need.

Real-life experiences in a design firm library, a collection of practical observations, suggestions. Right now the e-mail discussion groups fill this need but it would be helpful to have something more formal as well. Since many, if not most, firm librarians are solo these kinds of resources become even more important, especially to a new librarian. They would also help the solo librarian communicate the value of their work to their management - it becomes a recognized field rather than a nice addition if you can afford it. Some topics that come to mind are how to enlist help (i.e., students, MLS students, volunteers, etc.), how to communicate what you do and your value in ways that are meaningful to designers (i.e., visual quality, originality, quick), how to think like an architect (so you can provide them the information they need in a manner that's useful to them), how to say no gracefully (if you absolutely must).

Standards for organizing libraries and more information on CSI divisions and how to best organize and maintain in anticipation for growth. Also what to keep in online database v. what to keep in a physical library in terms of literature and samples.

Need more IT solutions to support some of the ideas I have for managing information. Our IT group is not large enough to perform the services I need.

Standards for firms like how many employees equal how many library hours?

Smaller corporate libraries are unique (each library is unique). I get more out of one-on-one or group discussions about specific products that we use.

At the time I started, the only info that really fit my job was a newsletter called the One-Person Librarian. I also learned some things from an admin assistant's newsletter published by NIBM. The library information available was either meant for larger libraries or libraries in the academic or public fields and much of it did not apply to my situation. 
Table 14 (continued)

\section{Desired support materials}

I would appreciate more firm related materials from ARLIS publications and more architecture related information from SLA.

Research software tied to specification.

Software to assist with cataloging, updating vendor contact information, reordering dates, timed reminders for updates if vendors have not been present.

Publications dedicated to managing solo libraries.

It would be great to have a plug-in resource that a firm like mine can use. Currently, we track these items using a proprietary job tracking systems, Excel files, and other miscellaneous means.

Specialty classification guidelines, code update notifications, more robust online vendor databases.

I am referring to information that is already developed, but that we do not have available as a result of not purchasing current copies (i.e., ASTM, ACI, and other references listed in our specifications that we do not have and cannot verify.

Third party computer program that holds contact information, website links, date of last update, etc. from manufacturer's and their representatives. This way, each firm does not have to create their own library catalog. It would be great if manufacturer representative were able to access this electronically and update their log information for their company, but not see the information of others. This would be a great way to streamline things, keep them organized, and save time on our end.

Database for cataloging vendor information, catalog information, etc. Database for magazines.

Up to date cataloging of available material technologies and their best applications organized by material type. 
Table 14 (continued)

\section{Desired support materials}

Of course, I can always figure out how to make the literature "work." But so much of the material is geared toward science and technology with more well-defined words. "Design," "architect," "engineering" are words that every industry uses so it makes it hard to search. Would like to see "case studies" on how to search. Would like it if vendors knew that just because I work with engineers doesn't mean I'm interested in patent information. More understanding of our industry is needed.

The overriding feature of the 18 responses given for this question is their diversity. Each response addresses a need or desire for a somewhat different type of support. The major themes of these comments reflect the desire for more architecture firm-related materials such as books and magazines focused on architectural design firm work, standards, guidelines, vendor databases, library catalogs, tracking systems, research software, specification and reordering software that updates and reminds, evaluation methods, and practical advice and suggestions for architectural design firm IM practice.

Question 12: How helpful are the following in supporting your ability to manage or assist with your design firm information management program(s), resources or services? (Please make a selection for each) 
Table 15

Descriptive Statistics for Survey Respondents' Ratings of Support Materials For Information Management Professionals in Architecture Firms

\begin{tabular}{lcccc}
\hline \multicolumn{1}{c}{ IM program support sources } & $M$ & $S D$ & $\begin{array}{c}\text { Number } \\
\text { responding respondents }\end{array}$ \\
\hline Books (training or management) & 2.25 & .622 & 32 & 56.1 \\
Book reviews & 2.54 & .611 & 35 & 61.4 \\
Book buying services/book sellers & 2.08 & .604 & 36 & 63.2 \\
Manuals or guides (training or & & & & \\
management) & 1.84 & .505 & 51 & 89.5 \\
Journal or magazine articles & 2.52 & .602 & 21 & 36.8 \\
Theses or dissertations & 2.08 & .774 & 39 & 68.4 \\
Subscription database vendors & 1.65 & .635 & 48 & 84.2 \\
Professional association membership(s) & 1.97 & .537 & 39 & 68.4 \\
Conference information/papers & 1.50 & .624 & 46 & 80.7 \\
Continuing education & 1.38 & .558 & 56 & 98.2 \\
Web sites & 2.00 & .728 & 35 & 61.4 \\
Blogs & 2.25 & .622 & 32 & 56.1 \\
Total answered question & & & 57 & 83.8 \\
Unanswered & & & 11 & 16.2 \\
Total participants & & & 68 & 100.0 \\
\hline
\end{tabular}

Three rating categories ranging from "Very helpful" (1) to "Somewhat helpful"

(2) and "Not at all helpful" (3) were provided as choices. Respondents report that continuing education, training manuals and guides, conference information/papers, and subscription database vendors as the most helpful. The mean ratings of these options fell within the limits of the "Very helpful" rating category. At the other extreme, books, book reviews and journal and magazine articles are rated on the average as least helpful, all of which mean ratings fall into the "Not helpful" categories. All others (booksellers, theses and dissertations, professional associations, Web sites, and blogs) are rated within the "Somewhat helpful" category. 
Question 13: Outside of paid salaries, is there a budget for the information management program(s) you manage or assist with or the resources or services you provide?

Table 16

Frequency Distribution of Existence or Absence of Budget For Survey Respondents' Information Management Program(s)

\begin{tabular}{lcc}
\hline \multicolumn{1}{c}{ Answer options } & $\begin{array}{c}\text { Number } \\
\text { responding }\end{array}$ & $\begin{array}{c}\text { Percent of } \\
\text { respondents }\end{array}$ \\
\hline Yes & 18 & 28.6 \\
No & 34 & 54.0 \\
Do not know & 11 & 17.5 \\
Total answered question & 63 & 92.6 \\
Unanswered & 5 & 7.4 \\
Total participants & 68 & 100.0 \\
\hline
\end{tabular}

An interesting indicator of the modest degree of support that IM practitioners receive in architectural design firms is the finding from this question that a majority of respondents indicated there is no budget for their IM programs beyond that provided for salaries. An additional $17.5 \%$ of the respondents reported that they aren't well enough informed about the funding of their programs to know whether there was a budget for resources or services.

Question 14: Approximately how long has or have the information management program(s) you manage or assist with, or the services you provide, existed in your office? 
Table 17

Frequency Distribution and Descriptive Statistics for Number of Years of Existence of Survey Respondent's Information Management Program(s) or Services in Their Firm Office

Part I

Information management program

You (no program, department or center) Library

Number Percent of Number Percent of Answer options responding Respondents responding respondents
(1) Less than 1 year
(2) $1+$ to 5 -
(3) $5+$ to $10-$
(4) $10+$ to $15-$
(5) $15+$ to 20 -
(6) $20+$ to 30 -
(7) $30+$ years
(0) N/A-Do not know

Total answered question

Unanswered

Total participants

1

26

6

8

2

5

1

2

50

18

68
2.0

51.0

11.8

15.7

3.9

9.8

2.0

3.9

74.0

26.0

100.0
1.7

10.3

8.6

12.1

12.1

8.6

34.5

12.1

84

16

100.0 
Table 17 (continued)

\section{Part II}

\begin{tabular}{|c|c|c|c|c|}
\hline \multirow[b]{3}{*}{ Answer options } & \multicolumn{4}{|c|}{ Information management program } \\
\hline & \multicolumn{2}{|c|}{ Archives department } & \multicolumn{2}{|c|}{ Records department } \\
\hline & $\begin{array}{c}\text { Number } \\
\text { responding }\end{array}$ & $\begin{array}{l}\text { Percent of } \\
\text { respondents }\end{array}$ & $\begin{array}{l}\text { Number } \\
\text { responding }\end{array}$ & $\begin{array}{l}\text { Percent of } \\
\text { respondents }\end{array}$ \\
\hline (1) Less than 1 Year & 0 & 0.0 & 0 & 0.0 \\
\hline (2) $1+$ to $5-$ & 3 & 7.0 & 2 & 4.8 \\
\hline (3) $5+$ to $10-$ & 2 & 4.7 & 1 & 2.4 \\
\hline (4) $10+$ to $15-$ & 1 & 2.3 & 0 & 0.0 \\
\hline (5) $15+$ to $20-$ & 0 & 0.0 & 0 & 0.0 \\
\hline (6) $20+$ to $30-$ & 5 & 11.6 & 4 & 9.5 \\
\hline (7) $30+$ Years & 11 & 25.6 & 10 & 23.8 \\
\hline (0) N/A-Do not know & 21 & 48.8 & 25 & 59.5 \\
\hline Total answered question & 43 & 63.2 & 42 & 61.8 \\
\hline Unanswered & 25 & 36.8 & 26 & 38.2 \\
\hline Total participants & 68 & 100.0 & 68 & 100.0 \\
\hline
\end{tabular}


Table 17 (continued)

Part III

\begin{tabular}{|c|c|c|c|c|}
\hline \multirow[b]{3}{*}{ Answer options } & \multicolumn{4}{|c|}{ Information management program } \\
\hline & \multicolumn{2}{|c|}{ Information center } & \multicolumn{2}{|c|}{ Resource center } \\
\hline & $\begin{array}{l}\text { Number } \\
\text { responding }\end{array}$ & $\begin{array}{l}\text { Percent of } \\
\text { respondents }\end{array}$ & $\begin{array}{l}\text { Number } \\
\text { responding }\end{array}$ & $\begin{array}{l}\text { Percent of } \\
\text { respondents }\end{array}$ \\
\hline (1) Less than 1 year & 0 & 0.0 & 2 & 5.3 \\
\hline (2) $1+$ to $5-$ & 2 & 8.8 & 3 & 7.9 \\
\hline (3) $5+$ to 10 & 1 & 4.4 & 3 & 7.9 \\
\hline (4) $10+$ to $15-$ & 0 & 0.0 & 0 & 0.0 \\
\hline (5) $15+$ to 20 & 1 & 4.4 & 3 & 7.9 \\
\hline (6) $20+$ to 30 & 0 & 0.0 & 1 & 2.6 \\
\hline (7) $30+$ Years & 2 & 8.8 & 7 & 18.4 \\
\hline (0) N/A-Do not know & 28 & 82.4 & 19 & 50.0 \\
\hline Total answered question & 34 & 50.0 & 38 & 55.9 \\
\hline Unanswered & 34 & 50.0 & 30 & 44.1 \\
\hline Total participants & 68 & 100.0 & 68 & 100.0 \\
\hline
\end{tabular}


Table 17 (continued)

Part IV

\begin{tabular}{lcccc}
\hline & \multicolumn{4}{c}{ Information management program } \\
\cline { 2 - 5 } & \multicolumn{3}{c}{ Knowledge center } & Other \\
\cline { 2 - 5 } & Number & Percent of & Number & Percent of \\
& responding & respondents & responding & respondents \\
\hline Answer options & 1 & 2.0 & 0 & 0.0 \\
\hline (1) Less than 1 year & 1 & 2.0 & 0 & 0.0 \\
(2) 1+ to 5- & 1 & 2.0 & 2 & 10.0 \\
(3) 5+ to 10- & 0 & 0.0 & 1 & 5.0 \\
(4) 10+ to 15- & 1 & 2.0 & 1 & 5.0 \\
(5) 15+ to 20- & 0 & 0.0 & 0 & 0.0 \\
(6) 20+ to 30- & 3 & 6.0 & 4 & 20.0 \\
(7) 30+ years & 27 & 79.4 & 12 & 60.0 \\
(0) N/A-Do not know & 34 & 50.0 & 20 & 29.4 \\
Total answered question & 34 & 50.0 & 48 & 70.6 \\
Unanswered & 68 & 100.0 & 68 & 100.0 \\
Total participants & & & & \\
\hline
\end{tabular}

This question attempted to allow for the possibility that respondents are in charge of assisting with one or more programs in the firm office. Most of the participants who responded to this question (an average of 63.4\%) that reference IM programs other than "You (i.e., the respondent) or the "Library" fell into the "N/A-Do not know" category. Only a minority of the respondents gave an answer other than "N/A - Do not know" with regard to the age of their organizations' records departments (40.5\%), information centers (17.6\%), knowledge centers (20.6\%), and Other (40\%). However, the most frequent number of years selected to characterize the longevity of all of the programs represented other than "You (i.e., the respondent) and "Information Center" was "30 years or more." Fifty-one percent of the participants who responded to this question and selected "You 
(no program, department or center)" indicated that they had been providing IM services for 1 to 5 years. The libraries in most of the responding firms $(67.3 \%)$ have been in operation for 30 or more years. Respondents representing "Information centers" were equally divided between "1 to 5 years" and " $30+$ years."

Question 15: Approximately how much square footage is devoted in your office to your information management program(s) or the resources or services you provide? 
Table 18

Frequency Distribution and Descriptive Statistics for Estimates of Square Footage

Dedicated to Survey Respondent's Information Management Program(s) in Their Firm Office

Information management program

Answer options

\begin{tabular}{cc} 
Information management program \\
\hline \\
My work space only & My work space PLUS all \\
program resources
\end{tabular}

(0) NA

Number Percent of Number Percent of

(1) 100 sq. ft. responding respondents responding respondents

(2) $200 \mathrm{sq} . \mathrm{ft}$.

(3) 300 sq. ft.

5

15.6

2.0

11

34.4

15.6

(4) 400 sq. ft.

9.4

0.0

5

3

(5) 500 sq. ft.

0.0

(6) 600 sq. ft.

0

4

(7) 700 sq. ft.

0

(8) 800 sq. ft.

1

(9) 900 sq. ft.

1

12.5

0.0

3.1

3.1

3.1

(10) 1000 sq. ft.

(11) 2000 sq. ft.

0.0

3.1

(12) More than 2000 sq. ft.

0.0

Total answered question

47.1

1

1

0

2

5

4.1

10.2

18.4

10.2

8.2

2.0

1

0

1

0

32

52.9

10.2

Unanswered

36

4.1

18.4

Total participants

68

100.0

8.2

8.2

72.1

27.9

100.0

Less than half of the participants $(47.1 \%)$ responded to this question in reference to their personal workspace, and, of those, $16 \%$ gave an "N/A" answer. Of those who did give a response, by far the most common answer was "100 square feet" devoted to personal workspace. Most respondents $(72 \%)$ gave an answer to this question in 
reference to the total workspace allocated to the IM program plus their workspace in their firm office. The distribution of the latter responses is as follows: $32.7 \%$ reported space allocations of 300 to 500 sq. $\mathrm{ft}$., and $34.8 \%$ reported space allocations of 1000 sq. $\mathrm{ft}$. or more. It would have been appropriate here to also request the total square footage for the office to create a percentage of total space allocated.

Question 16: Do any of the following store or provide access to the information, resources or services you or your information management program(s) provide(s)?

(Check any that apply)

Table 19

Frequency Distribution For Access And Storage Tools for Survey Respondents' Information Management Program's(s') Resource sand Services

\begin{tabular}{lcc}
\hline & Number & Percent of \\
Answer options & 45 & 71.4 \\
Intranet & 6 & 9.5 \\
Extranet & 40 & 63.5 \\
In-house library catalog & 8 & 12.7 \\
Other library catalogs & 17 & 27.0 \\
Subscription databases & 22 & 34.9 \\
Other vendor Web sites & 19 & 30.2 \\
Professional association Web sites & 15 & 23.8 \\
Other Web sites & 48 & 76.2 \\
Shelves or racks & 40 & 63.5 \\
File cabinets or drawers & 1 & 1.6 \\
None of the above & 63 & 92.6 \\
Total answered question & 5 & 7.4 \\
Unanswered & 68 & 100.0 \\
Total participants & & \\
\hline
\end{tabular}

The most common responses to the means of storing/accessing information are Intranet (i.e., server-based databases or document image files) and in-house library 
catalogs, as well as shelves or racks, and file cabinets or drawers. This pattern of responses seems to indicate that most materials are maintained in hard copy format and also as internally stored electronic documents. To a much lesser extent, respondents also reported the use of off-site repositories such as subscription databases, other vendor and professional association Web sites, and other Web sites of an undisclosed nature.

Question 17: Approximately how many people in your office (and entire firm, if applicable) utilize your information management program's(s') resources or the services you provide? (Please select nationwide as a separate amount that excludes your On-Site Office Total) 
Table 20

Frequency Distribution for Firm Offices And Number of End-users Served by Survey Respondents' Information Management Program(s)

\begin{tabular}{|c|c|c|c|c|}
\hline \multirow[b]{3}{*}{ Answer options } & \multicolumn{4}{|c|}{ Number of employees } \\
\hline & \multicolumn{2}{|c|}{ On-site office total } & \multicolumn{2}{|c|}{ Additional nationwide } \\
\hline & $\begin{array}{l}\text { Number } \\
\text { responding }\end{array}$ & $\begin{array}{l}\text { Percent of } \\
\text { respondents }\end{array}$ & $\begin{array}{c}\text { Number } \\
\text { responding }\end{array}$ & $\begin{array}{l}\text { Percent of } \\
\text { respondents }\end{array}$ \\
\hline$\overline{\text { None }}$ & 0 & 0.0 & & \\
\hline I don't know & 3 & 5.0 & & \\
\hline No other offices exist & & & 1 & 2.2 \\
\hline $\begin{array}{l}\text { Other offices exist, but none } \\
\text { are served }\end{array}$ & & & 8 & 17.4 \\
\hline $\begin{array}{l}\text { Other offices are served, but } \\
\text { don't know }\end{array}$ & & & 6 & 13.0 \\
\hline (1) 0 to 9 & 2 & 3.3 & 3 & 6.5 \\
\hline (2) 10 to 20 & 3 & 5.0 & 3 & 6.5 \\
\hline (3) 21 to 30 & 7 & 11.7 & 0 & 0.0 \\
\hline (4) 31 to 40 & 3 & 5.0 & 2 & 4.3 \\
\hline (5) 41 to 50 & 3 & 5.0 & 1 & 2.2 \\
\hline (6) 51 to 60 & 4 & 6.7 & 2 & 4.3 \\
\hline (7) 61 to 70 & 4 & 6.7 & 0 & 0.0 \\
\hline (8) 71 to 80 & 4 & 6.7 & 1 & 2.2 \\
\hline (9) 81 to 100 & 5 & 8.3 & 4 & 8.7 \\
\hline (10) 101 to 200 & 13 & 21.7 & 5 & 10.9 \\
\hline (11) 201 to 300 & 3 & 5.0 & 2 & 4.3 \\
\hline (12) 301 to 400 & 3 & 5.0 & 0 & 0.0 \\
\hline (13) 401 to 500 & 2 & 3.3 & 2 & 4.3 \\
\hline (14) 501 to 999 & 1 & 1.7 & 2 & 4.3 \\
\hline (15) Over 1000 & 0 & 0.0 & 4 & 8.7 \\
\hline Total answered question & 60 & 88.2 & 46 & 67.6 \\
\hline Unanswered & 8 & 11.8 & 22 & 32.4 \\
\hline Total participants & 68 & 100.0 & 68 & 100.0 \\
\hline
\end{tabular}

The most frequently mentioned number of people served by the library or IM program on-site is 101 to 200 . The next most frequent number of people served on-site is 
21 to 30 . As for nationwide service, $13 \%$ of the respondents reported that other offices are served, but they did not know the number of people they serve, and $17.4 \%$ of the respondents reported that other offices exist, but that none are served.

Question 18: Please indicate how active the following end-users are in utilizing your information management program's(s') resources or the information services you provide. (Select "N/A" if Not applicable) 
Table 21

Frequency Distribution of Occupational Categories Use of Survey Respondents'

Information Management Program(s)

Part I

User category

\begin{tabular}{|c|c|c|c|c|c|}
\hline \multirow[b]{2}{*}{ Response } & \multirow[b]{2}{*}{ Statistic } & \\
\hline & & Management & $\begin{array}{c}\text { Accounting } \\
\& \\
\text { Finance }\end{array}$ & $\begin{array}{c}\text { Marketing } \\
\& \\
\text { Sales }\end{array}$ & Legal \\
\hline $\begin{array}{l}\text { Very } \\
\text { active: }\end{array}$ & $\begin{array}{l}\text { Number } \\
\text { responding } \\
\text { Percent of } \\
\text { respondents }\end{array}$ & $\begin{array}{c}8 \\
12.9 \\
\end{array}$ & $\begin{array}{r}2 \\
3.2 \\
\end{array}$ & 12.1 & $\begin{array}{r}2 \\
3.4 \\
\end{array}$ \\
\hline $\begin{array}{l}\text { Somewhat } \\
\text { active }\end{array}$ & $\begin{array}{l}\text { Number } \\
\text { responding } \\
\text { Percent of } \\
\text { respondents }\end{array}$ & $\begin{array}{r}29 \\
46.8 \\
\end{array}$ & 9.5 & 18 & $\begin{array}{c}8 \\
13.6 \\
\end{array}$ \\
\hline Not active: & $\begin{array}{l}\text { Number } \\
\text { responding } \\
\text { Percent of } \\
\text { respondents }\end{array}$ & 18 & 58.7 & 43.1 & $\begin{array}{r}22 \\
37.3 \\
\end{array}$ \\
\hline $\begin{array}{l}\text { Not } \\
\text { applicable }\end{array}$ & $\begin{array}{l}\text { Number } \\
\text { responding } \\
\text { Percent of } \\
\text { respondents }\end{array}$ & 11.3 & 28.6 & 13.8 & 45.8 \\
\hline Total Rated & Category: & 62 & 63 & 58 & 59 \\
\hline
\end{tabular}


Table 21 (continued)

Part II

User category

\begin{tabular}{|c|c|c|c|c|c|}
\hline Response & Statistic & Architects & $\begin{array}{c}\text { Interior } \\
\text { designers }\end{array}$ & Engineers & Othe \\
\hline \multirow{2}{*}{$\begin{array}{l}\text { Very } \\
\text { active: }\end{array}$} & $\begin{array}{l}\text { Number } \\
\text { responding }\end{array}$ & 36 & 40 & 15 & 1 \\
\hline & $\begin{array}{l}\text { Percent of } \\
\text { respondents }\end{array}$ & 56.3 & 63.5 & 24.2 & 2.9 \\
\hline \multirow{2}{*}{$\begin{array}{l}\text { Somewhat } \\
\text { active }\end{array}$} & $\begin{array}{l}\text { Number } \\
\text { responding }\end{array}$ & 24 & 12 & 14 & 11 \\
\hline & $\begin{array}{l}\text { Percent of } \\
\text { respondents }\end{array}$ & 37.5 & 19 & 22.3 & 32.4 \\
\hline \multirow{2}{*}{ Not active: } & $\begin{array}{l}\text { Number } \\
\text { responding }\end{array}$ & 1 & 1 & 6 & 6 \\
\hline & $\begin{array}{l}\text { Percent of } \\
\text { respondents }\end{array}$ & 1.6 & 1.6 & 9.7 & 17.6 \\
\hline \multirow{2}{*}{$\begin{array}{l}\text { Not } \\
\text { applicable }\end{array}$} & $\begin{array}{l}\text { Number } \\
\text { responding }\end{array}$ & 3 & 10 & 27 & 16 \\
\hline & $\begin{array}{l}\text { Percent of } \\
\text { respondents }\end{array}$ & 4.7 & 15.9 & 43.5 & 47.1 \\
\hline \multicolumn{2}{|c|}{ Total Rated Category: } & 64 & 63 & 62 & 34 \\
\hline
\end{tabular}

There are considerable differences in the usage rates of IM resources and services by different occupational categories. The most active users are interior designers and architects, with $63.5 \%$ and $56.3 \%$ of respondents, respectively, indicating that these groups were "Very active." The least active users were those in the accounting and finance, and marketing and sales categories. Members of the legal department were also predominantly rated as either "Not active" or "Not applicable." Management was rated 
as "Somewhat active" by a plurality of respondents. Finally, the ratings of the engineers' activity were spread out evenly over the "Very active" and "Somewhat active" and "Not applicable" categories, suggesting that their use of these services varied widely among firms.

Table 22

Descriptive Statistics for Occupational Categories Use of Survey Respondents' Information Management Program(s)

\begin{tabular}{lccc}
\hline User category: & $\begin{array}{c}\text { Total } \\
\text { responses }\end{array}$ & $M$ & $S D$ \\
\hline Management & 61 & 2.18 & .669 \\
Accounting \& & & & \\
Finance & 61 & 2.82 & .446 \\
Marketing \& Sales & 58 & 2.36 & .722 \\
Legal & 59 & 2.63 & .609 \\
Architects & 62 & 1.43 & .533 \\
Interior designers & 62 & 1.26 & .486 \\
Engineers & 61 & 1.74 & .741 \\
Other & 34 & 2.28 & .575 \\
\hline
\end{tabular}

It should also be noted that in the "Other" category cost estimators, specifications writers, landscape designers, graphic designers and project coordinators were characterized as being "Somewhat active" users.

Question 19: Please identify the PRIMARY information need for each of the following: (One choice per row) 
Table 23

Frequency Distributions for Primary Information Needs by Occupational Category Part I

\begin{tabular}{|c|c|c|c|c|}
\hline \multirow[b]{3}{*}{ Answer options } & \multicolumn{4}{|c|}{ End-user } \\
\hline & \multicolumn{2}{|c|}{ Management } & \multicolumn{2}{|c|}{ Accounting \& Finance } \\
\hline & $\begin{array}{l}\text { Number } \\
\text { responding }\end{array}$ & $\begin{array}{l}\text { Percent of } \\
\text { respondents }\end{array}$ & $\begin{array}{l}\text { Number } \\
\text { responding }\end{array}$ & $\begin{array}{l}\text { Percent of } \\
\text { respondents }\end{array}$ \\
\hline Business or market info & 18 & 46.2 & 4 & 28.6 \\
\hline Vendor/product/materials info & 1 & 2.6 & 0 & 0.0 \\
\hline Archival drawings or plans & 2 & 5.1 & 0 & 0.0 \\
\hline Building and safety codes & 3 & 7.7 & 0 & 0.0 \\
\hline Legal/government info & 1 & 2.6 & 2 & 14.3 \\
\hline $\begin{array}{l}\text { Technical info (technological, } \\
\text { cad or other software) }\end{array}$ & 2 & 5.1 & 0 & 0.0 \\
\hline Design/creative/idea info & 4 & 10.3 & 0 & 0.0 \\
\hline Historical info & 2 & 5.1 & 2 & 14.3 \\
\hline Previous client/job info & 6 & 15.4 & 6 & 42.9 \\
\hline Total answered question & 39 & 57.3 & 14 & 20.6 \\
\hline Unanswered or Not applicable & 29 & 42.6 & 54 & 79.4 \\
\hline Total participants & 68 & 100.0 & 68 & 100.0 \\
\hline
\end{tabular}


Table 23 (continued)

Part II

\begin{tabular}{|c|c|c|c|c|}
\hline \multirow[b]{3}{*}{ Answer options } & \multicolumn{4}{|c|}{ End-user } \\
\hline & \multicolumn{2}{|c|}{ Marketing \& Sales } & \multicolumn{2}{|c|}{ Legal } \\
\hline & $\begin{array}{l}\text { Number } \\
\text { responding }\end{array}$ & $\begin{array}{l}\text { Percent of } \\
\text { respondents }\end{array}$ & $\begin{array}{l}\text { Number } \\
\text { responding }\end{array}$ & $\begin{array}{l}\text { Percent of } \\
\text { respondents }\end{array}$ \\
\hline Business or market info & 25 & 64.1 & 1 & 5.6 \\
\hline Vendor/product/materials Info & 3 & 7.7 & 0 & 0.0 \\
\hline Archival drawings or plans & 0 & 0 & 0 & 0.0 \\
\hline Building and safety codes & 0 & 0 & 1 & 5.6 \\
\hline Legal/government info & 0 & 0 & 13 & 72.2 \\
\hline $\begin{array}{l}\text { Technical info (technological, } \\
\text { CAD or other software) }\end{array}$ & 0 & 0 & 0 & 0.0 \\
\hline Design/creative/idea info & 3 & 7.7 & 0 & 0.0 \\
\hline Historical info & 1 & 2.6 & 0 & 0.0 \\
\hline Previous client/job info & 7 & 17.9 & 3 & 16.7 \\
\hline Total answered question & 39 & 57.3 & 18 & 26.5 \\
\hline Unanswered or Not applicable & 29 & 42.6 & 50 & 73.5 \\
\hline Total participants & 68 & 100.0 & 68 & 100.0 \\
\hline
\end{tabular}


Table 23 (continued)

Part III

End-user

\begin{tabular}{|c|c|c|c|c|}
\hline \multirow[b]{3}{*}{ Answer options } & & & & \\
\hline & \multicolumn{2}{|c|}{ Architects } & \multicolumn{2}{|c|}{ Interior designers } \\
\hline & $\begin{array}{l}\text { Number } \\
\text { responding }\end{array}$ & $\begin{array}{l}\text { Percent of } \\
\text { respondents }\end{array}$ & $\begin{array}{c}\text { Number } \\
\text { responding }\end{array}$ & $\begin{array}{c}\text { Percent of } \\
\text { respondents }\end{array}$ \\
\hline Business or market info & 1 & 1.7 & 0 & 0.0 \\
\hline Vendor/product/materials info & 23 & 39.0 & 39 & 73.6 \\
\hline Archival drawings or plans & 1 & 1.7 & 1 & 1.9 \\
\hline Building and safety codes & 14 & 23.7 & 0 & 0.0 \\
\hline Legal/government info & 0 & 0.0 & 0 & 0.0 \\
\hline \multicolumn{5}{|l|}{ Technical info (technological, } \\
\hline $\begin{array}{l}\text { CAD or other software) } \\
\text { Design/creative/idea info }\end{array}$ & $\begin{array}{c}8 \\
11\end{array}$ & $\begin{array}{l}13.6 \\
18.6\end{array}$ & $\begin{array}{c}2 \\
11\end{array}$ & $\begin{array}{c}3.8 \\
20.8\end{array}$ \\
\hline Historical info & 0 & 0.0 & 0 & 0.0 \\
\hline Previous client/job info & 1 & 1.7 & 0 & 0.0 \\
\hline Total answered question & 59 & 86.8 & 53 & 77.9 \\
\hline Unanswered or Not applicable & 9 & 13.2 & 15 & 22.1 \\
\hline Total participants & 68 & 100.0 & 68 & 100.0 \\
\hline
\end{tabular}


Table 23 (continued)

Part IV

\begin{tabular}{lcc}
\hline & \multicolumn{2}{c}{ End-user } \\
\cline { 2 - 3 } & \multicolumn{2}{c}{ Engineers } \\
\cline { 2 - 3 } & Number & Percent of \\
& respondents \\
Answer options & 0 & 0.0 \\
\hline Business or market info & 6 & 18.2 \\
Vendor/product/materials info & 1 & 3.0 \\
Archival drawings or plans & 18 & 54.5 \\
Building and safety codes & 0 & 0.0 \\
Legal/government info & & \\
Technical info (technological, & 7 & 21.2 \\
$\quad$ CAD or other software) & 0 & 0.0 \\
Design/creative/idea info & 0 & 0.0 \\
Historical info & 1 & 3.0 \\
Previous client/job info & 33 & 48.5 \\
\hline Total answered question & 35 & 51.5 \\
Unanswered or Not applicable & 68 & 100.0 \\
Total participants & & \\
\hline
\end{tabular}

The responses here can be summarized in terms of the information need(s) rated as relevant to each occupational group by the highest percent of respondents as follows: 
Table 24

Percentages of Primary Information Needs by Occupational Category

\begin{tabular}{llc}
\hline \multicolumn{1}{c}{ Occupation } & \multicolumn{1}{c}{ Primary information need } & $\begin{array}{c}\text { Percentage of respondents } \\
\text { indicating as primary } \\
\text { information need }\end{array}$ \\
\hline Management & Business or market info & 46.2 \\
Accounting \& Finance & Previous client/job info & 42.9 \\
Marketing \& Sales & Business or market info & 64.1 \\
Legal & Previous client/job Info & 17.9 \\
Architects & Legal/government Info & 72.2 \\
& Vendor/product/materials info & 39 \\
& Building and safety codes & 23.7 \\
Interior designers & Design/creative/idea info & 18.6 \\
& Vendor/product/materials info & 73.6 \\
& Design/creative/idea info & 20.8 \\
& Building and safety codes & 54.5 \\
Engineers & Technical info (technological, & \\
& CAD or other software) & 21.2 \\
& Vendor/product/materials info & 18.2 \\
\hline
\end{tabular}

The type of information predominantly used by each of the occupations follows intuitive expectations in that the primary information need(s) most commonly selected for each occupational category are related to their field of work.

Question 20: How are the information needs of the management and employees in your office (or entire firm, if applicable) determined? (Select all that apply) 
Table 25

Frequency Distribution for Survey Respondents' Methods of Determining The

Information Needs of The End-users of Their Information Management Program(s)

\begin{tabular}{|c|c|c|}
\hline Answer options & $\begin{array}{l}\text { Number } \\
\text { responding }\end{array}$ & $\begin{array}{c}\text { Percent of } \\
\text { respondents }\end{array}$ \\
\hline You or co-workers expertise about the industry & 42 & 67.7 \\
\hline $\begin{array}{l}\text { Networking with other information management } \\
\text { professionals outside our office }\end{array}$ & 18 & 29.0 \\
\hline Ongoing employee requests & 48 & 77.4 \\
\hline Firm meetings & 18 & 29.0 \\
\hline One-on-one conversations ${ }^{b}$ & 43 & 69.4 \\
\hline Surveys [online or hard copy] & 9 & 14.5 \\
\hline Other feedback forms ${ }^{c}$ & 3 & 4.8 \\
\hline E-mail inquiries ${ }^{d}$ & 30 & 48.4 \\
\hline Management reports & 2 & 3.2 \\
\hline None of the above & 3 & 4.8 \\
\hline Other ${ }^{\mathrm{f}}$ & 2 & 3.2 \\
\hline Total answered question & 62 & 91.2 \\
\hline Unanswered & 6 & 8.8 \\
\hline Total participants & 68 & 100.0 \\
\hline
\end{tabular}

A Includes benchmarking with other design libraries.

B Includes "lunch and learns" for AIA/CES credits with vendors, industry representatives.

${ }^{\mathrm{C}}$ Includes internal and external blogs.

${ }^{D}$ Includes e-mail or verbal requests to buy book or do research.

E Includes there is no specific way to get information.

F Includes specific needs identified for particular projects, corporate purchasing program.

Three methods of determining end users' information needs were selected with substantially greater frequency than any of the other alternatives:

1. You or co-workers expertise about the industry (19.3\% of responses, $67.7 \%$ of respondents)

2. Ongoing employee requests ( $22 \%$ of responses, $77.4 \%$ of respondents) 
3. One-on-one conversations (19.7\% of responses, $69.4 \%$ of respondents) Other frequently mentioned methods included:

1. E-mail inquiries ( $13.8 \%$ of responses, $48.4 \%$ of respondents)

2. Networking with other IM professionals outside our office (8.3\% of responses, $29.0 \%$ of respondents)

3. Firm meetings ( $8.3 \%$ of responses, $29.0 \%$ of respondents)

The one theme that emerged from these responses is that the primary means of ascertaining information needs was through informal communications. The methods representing more formalized communications (i.e., surveys and management reports) are among the least frequently selected methods.

Question 21: Are any of the following utilized to evaluate or measure the value of your information management program(s) or the information resources or services you provide? (Select only those that apply) 
Table 26

Frequency Distribution For Survey Respondents' Methods of Evaluating or Measuring

The Value of Their Information Management Program(s) or Services

\begin{tabular}{|c|c|c|}
\hline Methods of measuring IM program value & $\begin{array}{l}\text { Number } \\
\text { responding }\end{array}$ & $\begin{array}{l}\text { Percent of } \\
\text { respondents }\end{array}$ \\
\hline $\begin{array}{l}\text { Surveys or forms [web-based, e-mail, telephone or } \\
\text { hard copy] }\end{array}$ & 5 & 8.2 \\
\hline Informal feedback ${ }^{a}$ & 5 & 8.2 \\
\hline Meetings; votes or feedback & 15 & 24.6 \\
\hline Circulation statistics (if items are checked-out) ${ }^{b}$ & 7 & 11.5 \\
\hline $\begin{array}{l}\text { Log-in information (library catalog or Intranet } \\
\text { portal) }\end{array}$ & 4 & 6.6 \\
\hline None of the above & 37 & 60.7 \\
\hline Other & 0 & 0.0 \\
\hline Total answered question & 61 & 89.7 \\
\hline Unanswered & 7 & 10.3 \\
\hline Total participants & 68 & 100 \\
\hline
\end{tabular}

${ }^{A}$ Includes personal feedback either in person, via e-mail, or phone; immediate feedback each day on every transaction; word of mouth; feedback from individuals; verbal or e-mail feedback from individuals.

${ }^{B}$ Includes monthly usage reports; knowing what staff borrows by getting e-mails from them when they take items off the shelves.

The primary message emerging from responses to this question is that very little is being done in the way of evaluating IM programs. Of those who answered this question, $60.7 \%$ selected "None of the above" as their response. Given that all of the standard means of collecting evaluative information about programs are listed as alternatives, one can only conclude that minimal information of this nature is being collected. Where such information is being collected, it is being done through the less formal channels of "Meetings; votes or feedback" and "Informal feedback," which 
together account for 20 of the 36 responses that specified something other than "None of the above."

Question 22: Are any of these methods utilized to communicate news about your information management program(s) or the information resources or services you provide to management and employees? (Select only those that apply)

Table 27

Methods Survey Respondents Use to Communicate News About Their Information Management Program(s) to Management and Employees in Their Firm

\begin{tabular}{lcc}
\hline & Number & Percent of \\
Answer options & $\begin{array}{c}\text { Pesponding } \\
\text { respondents }\end{array}$ \\
\hline Intranet posts & 31 & 50.8 \\
E-mail messages & 47 & 77.0 \\
Firm Web site posts & 6 & 9.8 \\
Meetings/presentations & 25 & 41.0 \\
Newsletter [e-mail, online, or hard copy] & 6 & 9.8 \\
Press release or memo [e-mail or hard copy] & 2 & 3.3 \\
Flyers [posted or e-mailed] & 5 & 8.2 \\
Written reports to management & 4 & 6.6 \\
Informal face-to-face communication & 31 & 50.8 \\
Phone messages & 7 & 11.5 \\
None of the above & 2 & 3.3 \\
Other a & 5 & 8.2 \\
Total answered question & 61 & 73.5 \\
Missing & 7 & 26.5 \\
Total participants & 68 & 100.0 \\
\hline
\end{tabular}

${ }^{\text {A }}$ Also mentioned via write-in responses were: keeping a Wiki of one's activities, product displays, occasional e-mails to remind others that the product database has been updated, .pdf files of databases, and Twitter.

The most frequent methods of communicating information about IM programs to management and employees are e-mail messages, intranet posts, informal face-to-face 
communication and meetings/presentations. Together, these four methods accounted for $78.4 \%$ of the total number of responses elicited. These methods exhibit a fairly even split between informal methods (i.e., e-mail messages and informal face-to-face communication) and formal methods (i.e., Intranet system posts, and meetings and presentations).

Question 23: List any professional associations you have joined that specifically support your architectural design firm information management work: (Please specify abbreviation and name, if possible, so it can be clearly identified) 
Table 28

Professional Associations Survey Respondents Have Joined to Support Their Architectural Design Firm Information Management Work

\begin{tabular}{lcc}
\hline \multicolumn{1}{c}{ Professional Associations } & $\begin{array}{c}\text { Number } \\
\text { responding }\end{array}$ & $\begin{array}{c}\text { Percent of } \\
\text { respondents }\end{array}$ \\
\hline Special Libraries Association (SLA) & 16 & 47.1 \\
Construction Specifications Institute (CSI) & 9 & 26.5 \\
American Institute of Architects (AIA) & 7 & 20.6 \\
International Interior Design Association (IIDA) & 4 & 11.8 \\
US Green Building Council (USGBC) & 4 & 11.8 \\
Leadership Energy Environmental Design (LEED) & 3 & 8.8 \\
Resource Directors Association (RDA) & 2 & 5.9 \\
American Society of Interior Designers (ASID) & 2 & 5.9 \\
Boston Society of Architects - Information & & \\
Resource Wizards & 2 & 5.9 \\
International Code Council (ICC) & 2 & 5.9 \\
National Fire Protection Association (NFPA) & 2 & 5.9 \\
American Library Association (ALA) & 2 & 5.9 \\
Art Libraries Association (ARLIS) & 1 & 2.9 \\
Records Management Association (ARMA ) & 1 & 2.9 \\
Berks County Library Association (BCLA) & 1 & 2.9 \\
Association for Information and Image & & \\
Management (AIIM) & 1 & 2.9 \\
National Council for Interior Design Qualification & & \\
(NCIDQ) & 1 & 2.9 \\
MasterSpec@ & 1 & 2.9 \\
American Society for Testing and Materials & & \\
(ASTM) & 1 & 2.9 \\
Total answered question & 34 & 50.0 \\
Missing & 34 & 50.0 \\
Total participants & 68 & 100.0 \\
\hline
\end{tabular}

Only 34 , or $50 \%$, of the survey respondents reported belonging to a professional association. Eighteen of the respondents indicated that they are members of two or more organizations. A total of 20 professional associations are reported. Thirteen of which 
are industry-oriented and have architectural, building and construction, design, and regulatory focus. Seven are library-related and they include the number one choice, SLA, with $47 \%$ of the respondents having joined. The six remaining from the library group received only one or two mentions each. The number two and three choices are the AIA and CSI at $26.5 \%$ and $20.6 \%$ of the respondents, respectively. 


\section{Chapter 5}

\section{Conclusion}

\section{Discussion}

This research study seeks to define library and IM program functions, and librarian and IM professionals' roles in architectural design firm offices. In addition, to determine if the people in charge feel the existing professional literature, support materials and other sources available, are sufficient to support their IM work in architectural design firm offices. To address the goals of this research in this discussion, the findings have been grouped based on the general focus of the study's three research questions: IM Programs, IM Professionals, and Level of Support for IM Professionals.

\section{IM Programs}

The names of the libraries and IM programs in architectural design firms are as varied as the information needs of the people they serve. The most common name is "library" and second most prevalent included the use of the term "center." In most cases both terms are modified by a multitude of descriptors such as materials, resource, design and product. It is being suggested here that the descriptors highlight what is considered to be the most important functions of the programs.

The majority of survey respondents do not know when the libraries or IM program(s) they managed or assisted with had been established in their office. As a result, these respondents indicated how long they have been providing IM services in the firm, which is predominantly 1 to 5 years. However, the literature review combined with the other responses suggest that libraries and IM programs by other names appear to have 
been a part of architectural design firm offices for quite some time now. Of the respondents that did know, the majority reported that their libraries, archives, records departments, and majority of "Other" programs have been in existence for "30 years or more."

Two hundred and eighteen out of the 250 firms report having one or more libraries or IM programs in their firm office. There is also acknowledgment by the survey respondents that there are additional IM programs their firm offices that are the responsibility of other employees such as libraries, archives departments, records departments, and materials centers, however, the total number is undetermined. It would have been helpful to request the total number of programs the respondents represented in this study to confirm the total number of programs for each firm office. The most substantial number of respondents chose not to specify any years of operation for programs or services, which implies that no other programs exist.

Space. It is difficult to evaluate space allocations for IM program resources without information about the total amount of space in the respondents' facilities. The latter information would have permitted the interpretation of the responses in terms of percentages of available space and might have revealed more about differences in degrees of emphasis placed upon the program resources. Nonetheless, the firms do appear to be allocating 300 to 900 square feet on the average. A substantial number of respondents also selected over 1000 square feet. The pattern of responses may be reflective of the range and distribution of firm sizes in the sample, but this is unsubstantiated. 
Resources. Despite the fact that the majority of respondents report having no budget or not knowing of a budget for their programs, costly subscription databases, books, magazines, and newspapers, as well as building and safety code information, appear to be the most highly present resources offered in an architectural firm library or IM center. Newsletters, materials samples and vendor catalogs are also essential, but they are typically obtained at no cost. Resources are delivered utilizing Intranet, Internet, and library catalogs, as well as via shelf racks, file cabinets, and drawers. Digital delivery in this new information age is obviously imperative, but resources in physical form are still in demand and the need for physical space to house them is still a necessity. A very small percentage of respondents report the use of Extranets. It is possible that there is no need to share information with outside entities, or that the development of new technologies has enabled firms to store more information in-house without bogging down their internal systems.

End-users. The majority of respondents report that their libraries and IM programs serve 0 to 100 people in the firm. The next number of people served by the IM programs on-site is 101 to 200 . Not surprisingly, the most active users of the programs and services are architects and interior designers. A large number of respondents selected that other offices exist, but that they are not served. Off-site numbers are difficult to quantify in that, respondents specified equally that they do not know how many people are served off-site and also that 81 to 200 people served off-site. This distribution of people served probably may suggest that smaller firms have fewer offices and would be 
less likely to provide services to other sites. Generally, the larger the firm, the more people served in other offices nationwide.

The multifaceted nature of the present-day architectural firm requires that the information provided serves several professional disciplines in one office. The primary information needs of interdisciplinary architectural firm libraries are as follows: (a) architects and interior designers want vendor information; (b) engineers require building and safety code information; and (c) management, accounting and finance, as well as marketing and sales departments, are primarily interested in business and market information; and the legal departments need legal information. The primary information needs of each occupational category follows intuitive expectations in that they are directly related to the field of work.

\section{IM Professionals}

During the phone inquiry stage, many firms reported that they had "librarians" managing their libraries and IM programs by other names, but that they had been laid off within the past year. In addition, the responsibility to manage or assist with administering the libraries or IM programs has been delegated to architects, interior designers, specifications writers, administrative assistants, and office managers. These professionals are included in the survey research to learn more about the programs.

The profile of the IM professional managing or assisting with IM programs, resources, and services, in architectural design firm offices is one of a college-educated professional that is divided evenly between those whose primary job is managing or assisting with the IM program, and those having it as a secondary or tertiary 
responsibility. About one quarter of the IM professionals hold library degrees, and none have obtained a doctorate. There is also a small presence of librarians who are employed as outside consultants for a number of firms on a part-time basis, and whose primary job is to manage the firm's library or IM program's resources or services.

However, the survey responses reflect that in most cases there are 2 to 3 people managing and assisting with the libraries and IM programs. Close behind are situations whereby the library or IM program is the sole responsibility of one professional with no other employees dedicated to help with the resources and services. The amount of time the professionals spend on administering the IM programs per week is equally divided between 8 hours or less and 32 hours or more. This correlates with the discovery that half of the respondents report that a library or IM program is their primary job focus, and the other half that reported it to be a secondary or tertiary responsibility. It would be interesting to know if the fewer hours devoted per week are attributed to the firms being smaller or if it is simply not a priority for management. It is possible that the firm has decided that only a certain number of hours per week are to be dedicated to the library or IM program.

The primary job duties of the IM professionals include cataloging and classifying information, conducting research, meeting with vendors, and developing collections. A much smaller minority of respondents perform other duties, such as evaluating or measuring the value of the programs or services, archiving and preserving, color coding, or budgeting. Developing a strategic plan and digitizing library materials are rarely the responsibility of a librarian or $\mathrm{IM}$ professional in these firms. 
The survey respondents in this research study are employed in the firms' corporate headquarters. This may explain why they are not only responsible for providing magazine, trade journal, newsletter, and newspaper subscriptions, but also administering library catalogs, subscription databases, building and safety code information, and vendor information, to offices nationwide. It may be that ensuring the delivery of these types of resources is necessary for architecture firms' integration of information, or simply that their availability in digital form, make them relatively easy to share.

Surprisingly, in this new economic climate, evaluating or measuring the value of the information management programs or the information resources or services the librarians and IM professionals provide, does not seem to be a priority. Most of the librarians and IM professionals utilize more informal means of evaluating value in the form of votes and feedback at meetings, and via one-on-one conversations. Rarely do they employ more formal evaluation methods, such as surveying end-users or measuring circulation or log-in statistics.

It is difficult to understand why evaluation would not be an essential function of the librarian's or IM professional's job. It is possible that if value is not tied directly to salaries then the IM professionals may feel it is not necessary. The very fact that the firm has implemented an IM program, and dedicated an employee or employees to manage or assist with it, certainly implies that there is perceived value. Nonetheless, value of resources and services, particularly if time and money is involved, does need to be continually established and communicated, particularly in light of the current recession 
and job layoffs. Most of the professionals in charge or assisting with the libraries and IM programs recognize the importance of communicating news about new developments, resources and services utilizing e-mail messages, Intranet systems, and also via meetings, and presentations. However, the value of the resources and services is tied directly to the amount of time and money invested in locating the most up-to-date and relevant information, and the ability to make it easily accessible to management and employees of the firm in the most desirable formats.

The information needs of the management and employees of the firm are determined primarily based on librarian or IM professional's own industry expertise and also through more informal means such as one-on-one conversations with co-workers and requests, as well as e-mail inquiries. Networking with other librarians and IM professionals is also reported as an important way to identify needs and current trends.

\section{Level of Support for IM Professionals}

The IM professionals were equally divided in their perceptions of whether the professional literature, training materials and other sources currently available support their ability to administer their IM programs, resources and services. One third reported they felt the sources were sufficient. This appears to reflect knowledge of sufficient sources since the option of "I don't know" was also provided. However, the findings of this research study suggests that much of the support materials that the librarians and Im professionals utilize are primarily generated by architectural industry-related sources, not the library field. 
With regard to the types of sources the respondents find most helpful in supporting their IM work; continuing education, training manuals and guides, conference information or papers, and subscription database vendors, are reported to be the most helpful. Professional associations, theses or dissertations, and book buying services are also identified as somewhat helpful, and books, book reviews and journal/magazine articles, blogs and Web sites are not helpful. Since no current manuals or guides specifically related to architectural design firm IM work were found during the course of this research, it may be safe to say that respondents may be referring to manuals and guides generated within the architectural field. The selection of theses or dissertations as being somewhat helpful is surprising since locating and accessing to this type of work can be a very time consuming task. The identification of magazine and journal articles as least helpful is also surprising in light of the fact that this literature provided some of the timeliest and most applicable information relating to $\mathrm{IM}$ work in architectural design firm offices, and many sources located primarily in architectural industry magazines and journals.

It would have been more meaningful here to also assess if the sources the librarians and IM professionals find most helpful are generated by the architectural or library fields, as well as if they are provided to the IM professionals by, for example, booksellers or subscription database vendors or if the IM professionals must locate the sources themselves. The phrasing of the question may have also confused the respondents as to whether they were identifying how helpful the existing resources are 
for their end-users versus helpful to them in administering their programs, the resources, and services.

Due to the proprietary nature of these firms, the IM professionals were not asked in the survey to identify the specific names of guides, training materials or any product names that they utilize to organize, store, maintain or deliver their firm's information, or if they felt that these sources could be improved upon. If the professionals offered information of this kind it is duly noted below.

During the phone inquiry, many IM professionals made it a point to acknowledge standards, reference materials, and resources they utilize that are generated by professional associations specifically related to the architectural, and building and construction, industries. Support materials developed by industry organizations that address technical standards for materials, products, systems, and services, were mentioned by several IM professionals as helpful to them in organizing information they provide to their end-users. Some of the sources, and the organizations that created them, are as follows: ASTM International's Standards Catalog; United States Green Building Council's (USGBC) Leadership in Energy and Environmental Design's (LEED) Green Building Rating System; American Concrete Institute (ACI); and National Industries Company for Building Materials (NIBM). The Construction Specifications Institute's (CSI) MasterFormat ${ }^{\mathrm{TM}}$ schedule, which provides an organizational scheme for building and material products that is also searchable in databases, is also mentioned quite frequently by IM professionals as being a resource upon which many IM professionals in architectural offices depend. 
Many respondents also mentioned that they are heavily reliant on specialty software developed by for-profit publishers, such as McGraw-Hill's Suites ${ }^{\mathrm{TM}}$ program and Stallworth Enterprise's Tradesources.net ${ }^{\mathrm{TM}}$. Both programs have been created specifically for architecture design firms to organize, catalog, and classify, their vendor information. Respondents that do not utilize software that has been developed specifically for use in architecture firms, report they simply develop their own databases and organizational systems utilizing Microsoft, Windows, or other software programs they have in-house. The use of software programs specifically designed for architectural firms, and the need to create database systems in these architectural offices, is consistent with the responses that specify databases as being what is most needed to support librarians and IM professionals working in architectural design firm offices. Either these professionals are not aware of these sources or they feel they need to be improved upon.

Issues with the software; and more specifically database packages, developed for architecture firms are mentioned. Several respondents complain that McGraw-Hill Suites $^{\mathrm{TM}}$ is not updated regularly enough by the participating vendors. Others expressed concern about the ownership of the information they contribute to Stallworth Enterprise's Tradesources.net ${ }^{\mathrm{TM}}$, whose content is provided by the subscribers.

A third of the respondents report they do not feel the existing professional literature, sources, and materials are sufficient to support their library and IM work. Of this group, 18 of the 22 people reported on what they would like to see developed. The primary need appears to be in the area of information technology (IT). Software to manage information in the form of library catalogs, research software, cataloguing 
software for material technologies and types of materials and "their best applications," as well as databases for magazines, contact information for clients and projects, were specified. Most importantly, cataloging vendor products and organizing contact information with automatic updates for discontinued products and materials, timed reminders for reordering dates, and changes in vendor representatives appear to be paramount. Librarians and IM professionals express a need for a system that allowed individual vendors to update their own information in a database without having access to competitors' information. This implies that this type of database poses issues with proprietary information that might be a deterrent for that level of vendor participation. However, this issue can be easily overcome by creating a database within an Intranet system where access can be limited.

Developing standards for architectural design firm libraries or IM practice whereby job-related duties can be measured against the number of employees being served is also mentioned. In addition, librarians and IM professionals suggest the need for more evaluation methods and tools that demonstrate the value of a librarian, library resources, and services, and that can also be communicated in a meaningful way to management. Standards for setting up and maintaining libraries, as well as allowing for and measuring growth, are also requested.

Finally, several of the respondents reported difficulty with locating information in the professional literature about architectural design firm library work. The respondents communicated they felt the literature is merged with academic and other library information, and that it seems to be geared towards science and technology. Another 
problem searching is caused by the very nature of the key words that tend to be used such as "library," "architecture," and "design." All of these discoveries are consistent with the findings of this researcher, who conducted extensive searches and encountered the same challenges. Any number of combinations of these search terms retrieves information about libraries designed by architecture firms rather than libraries in architecture firms. Searching guidelines may need to be developed to help classify this type of library and IM work in a more definitive way within the special library, corporate or art library literature or to possibly even distinguish it's own category. In addition, it is important that library science professionals communicate information directly to architectural IM professionals that supports their particular type of library work and provides suggestions on how to search for, and locate, information within library science literature utilizing library science criteria.

Other issues within the library field have to do with the fact that respondents feel much of the literature is directed at larger libraries rather than smaller libraries and solo librarians and thus does not apply to their practice. A desire for a publication for solo librarians is requested, as well as more firm-related materials from ARLIS and SLA. An electronic or print resource that identifies the crucial magazines and books that every architecture firm library should have is also requested. Books with case studies that illustrate real-time experiences in architecture firms that is focused on how to search and find information, measure and communicate value, enlist the help of students, provide information in a way that is most useful to management and employees of the firm, and finally, select physical versus digital resources, is also conveyed. 
The final third of the respondents reported that they do not know if the existing literature, materials and sources are sufficient to support their IM work. This may imply that these professionals do not spend the time to locate information that facilitates their IM work, or that they do not know where to look and, therefore, are not aware of what is available. It would have been helpful here to establish a correlation between job titles and responses to better understand the reasons behind one's familiarity with, and expertise in, locating support materials. Also, if the job title designated the library or IM function is a secondary or tertiary responsibility, then the amount of time available, or interest in, focusing energy on locating support materials, might also be a factor.

A total of 20 professional associations are identified by half of the survey respondents. The fact that only half of the participants report suggests that the other half do not belong to any professional associations. The respondents who identified associations appear to be members of two or more organizations. The professional association that is reported twice as often as the second and third highest is the SLA. However, only four of the 20 professional associations identified are library related; the rest are architecture and building and construction.

Surprisingly, the second most highly reported association is the Construction Specifications Institute (CSI). It is more popular than the AIA, despite the fact that the respondents represent architecture firms, not construction. Nonetheless, architectural work depends on the building and construction industry. CSI obviously provides needed information and tools that the IM professionals can utilize in their practice. This may also suggest that the librarians and $\mathrm{IM}$ professionals are acquiring information in areas 
that the architects and other end-users are not familiar with, or that they choose not to spend time researching on their own.

Again, it would have been helpful here to draw a correlation between the job titles, education and the professional association memberships reported. This would have indicated a basic level of training and exposure to particular professional associations, as well as whether the IM professional has a predominantly a library-related focus or more categorical focus.

\section{Further Research}

Now that a special library population; its' people and programs, have been established and described, there are some interesting possibilities for further research on the topic. A future study might compare the group in this study with librarians and libraries in corporate settings where the special library concept has been more fully implemented and supported. It would also be beneficial to compare library programs in established special libraries, such as medical and law libraries, to those in architectural firms to ascertain the characteristics that differentiate mature from incipient implementations of programs. It might also prove useful to compare the benefits of the work of trained, full-time professionals in these other libraries to that of architectural design firm employees whose library or IM work is a part-time, or a secondary or tertiary responsibility.

Research in the form of a case study whereby the end-users of the libraries and IM programs in architectural design firm offices are interviewed to determine the value of the resources and services provided would also be beneficial. However, due to the 
proprietary nature of these for-profit environments, it may be difficult to enlist participation in a study of that kind. While it would have been desirable to establish the value of IM professionals and programs in this study, a population and programs had to be discovered and defined first. Nevertheless, it is hoped that this study will lay the foundation for more value-based research in the future. In the meantime, librarians and IM professionals working in architecture firms can be encouraged and supported to more formally measure and evaluate the value of their programs, resources, and services provided.

\section{Conclusion}

Recent downturns in the economy have adversely affected the presence of employed librarians and IM professionals, as well as the existence of libraries and IM programs in architectural design firm offices. Nonetheless, this research study establishes a prevalence of librarians and IM professionals, as well as libraries and IM programs, that has not been documented before. Surges in design firm revenue in the past combined with the development of new technologies, and scarce amount of research and data on this special library population, make this study timely and significant. Being exploratory in nature, however, it should be considered as setting the stage for further research in this special sphere of library work in the future. 


\section{References}

Ahrensfeld, J., Christianson, E., \& King, D. (1986). Special libraries: A guide to management. Washington, DC: Special Libraries Association.

American Library Association (ALA). (2009). Retrieved from http://www.ala.org/ala/aboutala/offices/library/libraryfactsheet/alalibraryfactsheet $1 . \mathrm{cfm}$

American Library Directory 2006-2007. (2007). Medford, NJ: Information Today.

American Society of Interior Designers (ASID). (n.d.). Retrieved from http://www .asid.org/knowledge/

Architectural Record. (2008). Top 150 architectural design firms. Retrieved from http://archrecord.construction.com/practice/top150/0806top150-1.asp.

Art and Architecture Thesaurus Advisory Committee. (1996). Art and architecture thesaurus sourcebook. (Occasional Paper No. 10). Ottawa, Canada: Art Libraries Society of North America.

Ballast, D. K. (1990). Taming the facts: Five ways to improve information management and thus productivity and quality control. Architectural Record, 178(11), 39-42.

Barrow, L. (2006, August). Information technology and client relationship management in architecture: Building competitive advantage. Dissertation Abstract International, 44 (4), 1544. (ATT1432872)

Brown, K. (2001, October). Information technologies and the architecture community. Paper presented at Symposium Proceedings of the Federal Facilities Council. Retrieved from Proquest at http://books.nap.edu/openbook.php?record_id=10217\&page $=15$

Broxis, P. F. (1968). Organizing the arts. Hamden, CT: Archon Books \& Clive Bingley Ltd.

Christianson, E. (1980). Toward a better understanding of special libraries. Special Libraries, 71(2), 146-153.

CNNMoney.com. (2007). Fortune 500: Annual ranking of America's largest corporations. New York, NY: Cable News Network LP, Time Warner Company.

Conkling, T., \& Musser, L. (2001). Engineering libraries: Building collections and delivering services. New York, NY: Science \& Technology Libraries. 
Craig, S. (2003). Survey of current practices in art and architecture libraries. Journal of Library Administration, 39, 91-107.

Directory of Special Libraries and Information Centers. (2007). New York, NY: Thomson Gale.

Dodd, K., \& Ball, H. (2005). ARLIS/NA 2004 art \& architecture librarians and visual resource professionals compensation survey. Washington, DC: Art Libraries Society of North America.

Dommeyer, C. J., \& Moriarty, E. (2000). Comparing two forms of an e-mail survey: Embedded vs. attached. International Journal of Market Research, 42(1), 39-50.

Engineering News-Record. (2006). Top 500 design firms. Retrieved from http://enr.construction.com/people/topLists/topDesignFirm/topdesign_1-50.asp.

Hamlin, T. (1939). Some European architecture libraries: Their methods, equipment, and administration. New York, NY: Morningside Heights.

International Federation of Library Associations (IFLA). (n.d.). Art libraries section. Retrieved from http://www.ifla.org/en/art-libraries

International Interior Design Association (IIDA). (n.d.). Knowledge center. Retrieved from http://knowledgecenter.iida.org/Research.aspx

Irvine, B. J. (Ed.). (1991). Facilities standards for art libraries and visual resources collections. Englewood, CO: Libraries Unlimited.

J. Paul Getty Research Institute. (2007). Art and architecture thesaurus [online]. Retrieved from http://www.getty.edu/research/institute/

Jones, L., \& Gibson, S. (1986). Art libraries and information services: Development organization, management. Orlando, FL: Academic Press.

Kalt, K. (1979). Organizing and managing information in architectural, engineering and consulting firms: analysis of a 1978 survey. Newington, CT: Professional Management Services Journal.

Kalt, K. (1980). Color coding the firms' library for fast simple retrieval. Architectural Record, 166(1), 66-67.

Kanoglu, A., \& Arditi, D. (2001), A computer-based information system for architectural design offices. Construction Innovation, 1(1), 12-14. 
Lohmann, W. (May 1993). Specifications: information resources. Progressive Architecture, 64. Retrieved from Factiva at http://www.factiva.com/

Matarazzo, J.M., Prusak, L., \& Gauthier, M.R. (1990). Valuing corporate libraries: A survey of senior managers. Washington, DC: Special Library Association.

Meho, L., \& Tibbo, H. (2003). Modeling the information-seeking behavior of social scientists: Ellis's study revisited. Journal of the American Society of Information Science and Technology, 54, 570-587.

Mays, P. (1997). Managing the firm's archives. Architecture, 86, 12.

McRae, L., \& White, L. (1998). ArtMARC sourcebook, cataloging art, architecture, and their visual images. Chicago, IL: American Library Association Editions.

Mount, E. (1982). Ahead of its time: The Engineering Societies Library, 1913-80. Hamden, CT: Shoe String Press.

Pacey, P. (1977). (Ed.). A reader in art librarianship. New York, NY: International Federation of Library Associations and Institutions.

Primary Research Group. (2001). Survey of academic \& special libraries. New York, NY: Primary Research Group.

Protzen, J. P. (1999) Managing technological change in architectural practice: The role of computers in the culture of design. Dissertation Abstract International-A, 59(08), 2755. (ATT9901976)

Radonsky, S. (1991). Management: The firm library. Progressive Architecture, 72(65), $1-5$.

Resources Directors Association. (2007). Job responsibilities. Retrieved from http://www.rdanet.org/about.html?subsect=responsibilities

Ross, J. (1992). Cataloging architectural drawings: A guide to the fields of the RLIN Visual Materials. (Topical Paper No. 1). Tucson, AZ: Art Libraries Society of North America. Retrieved from http://www.arlisna.org/resources/ otherpubs/otherpubs_index.html

Sanders, K. (1997). Firm wide networks: Intranets in architectural firms. Architecture, 86(3), 122-126.

Schluntz, R. L. (1974). A survey of architectural library resources. Journal of Architectural Education, 32, 64-68. 
Shaw, J. (1995). Architectural and design firm libraries: A survey. Special Libraries, $86(3), 152--63$.

Shillaber, C. (1957). Architecture libraries: Their resources. Journal of Architectural Education, 12(2), 26-30.

Special Library Association. (1998). Survey reveals information professionals significant role in purchasing decisions. (Press release). Retrieved from http://www.sla.org/content/SLA/pressroom/pressrelease/1999pressrelease 19925.cfm

Special Library Association. (2006). Fortune 500 companies and special libraries. (Press release). Retrieved from http://www.sla.org/content/resources/research/ researchlinks/f500.cfm.

Special Library Association. (2009). Research statement. Retrieved from http://www.sla.org/content/resources/research/rsrchstatement.cfm

Engineering News Record. (2006). Technology and sustainability are surging. Retrieved from http://www.sla.org/content/resources/research/unitsurveys.cfm

U.S. Census Bureau. (2006). Service annual survey 2004. Retrieved from http://www.census.gov/compendia/statab/tables/07s1259.xls

U.S. Department of Labor Bureau of Labor Statistics. (2007). Occupational outlook handbook. Retrieved from http://www.bls.gov/oco/ocos038.htm 


\section{Appendix A: Bibliography}

An, X. (2006). On integration best practice of architectural project archives. Records Management Society Bulletin, 130, 33-38.

Architects' offices, resource library. (1983). Interior Design, 83, 234-235.

Art Libraries of North America. (2006). 2004 Art \& architecture librarians and visual resource professionals compensation survey. Ottawa, Canada: Art Libraries of North America.

Art Libraries Society of North America. (1983). Standards for art libraries and fine arts slide collections. Tucson, AZ: Art Libraries Society of North America.

Balay, R. (Ed.). (1996). Guide to reference books (Rev. ed.). Chicago, IL: American Library Association.

Ball, H., Gerlich, T. G., \& Glassman, P. (2007). Core competencies and core curricula for the art library and visual resources professions. (Occasional Paper No. 15). Lanham, MD: Art Libraries of North America and Scarecrow Press.

Ballast, D. K. (1987). Creative records management: A guide for architects, engineers, and interior designers. Newman, MA: Practice Management Association.

Ballast, D.K. (1987). Records and information management in architectural, engineering and interior design firms: A bibliography. Monticello, IL: Vance Bibliographies.

Boucher, J. (1978). How to fit a library into your office. Consulting Engineer, 50(2), 68-73.

Bowden, R., \& Wijasuriya, D. (1995). Art, architecture and design libraries. New Providence, NJ: R. R. Bowker.

Brownlee, D. (2000, May). We invented architectural history to study ourselves: Buildings and their records. Lecture presented at the Architectural Records Conference of the Conservation Center for Art and Historic Artifacts, Philadelphia, PA.

Burke, C. R. (1986). Records management in an architectural firm. Skidmore, Owings and Merrill Science and Technology Libraries, 6, 69-82.

Burnett, L. (2004). Resource central: Creating a successful design library--nobody's shushing anyone here, least of all the librarian. Contract Commercial Interior Design and Architecture, 46(7), 33. 
Burns, J. A. (2000, May). The digital revolution and architectural records: HABS/HAER at the threshold of the twenty-first century. Lecture presented at the Architectural Records Conference of the Conservation Center for Art and Historic Artifacts, Philadelphia, PA.

Byrnes, S. C. (1989). Meeting the information needs of practicing architects: The architectural library of the future: Complexity and contradiction. Ann Arbor, MI: University of Michigan Press.

Council on Library and Information Resources. (2005). Library as place: Rethinking roles, rethinking space. Retrieved from http://www.clir.org/pubs/ abstract/pub129abst.html

Ehresmann, D. (Ed.). (1984). Architecture: A bibliographic guide to basic reference works, histories, and handbooks. Littleton, CO: Libraries Unlimited.

Gawne, E. (2003). Persuading architecture faculty that library instruction is essential: A Yale case study. Journal of Society of Archivists, 24, 175-180.

Gillingham, H., \& Roberts, B. (2006) Implementing knowledge management: A practical approach. Journal of Knowledge Management Practice, 7(1), 1-12.

Gonchar, J. (2006). Integrated firms dominate architecture practice ranking. Architectural Record, 194, 42.

Horst, B. (2000, May). Guidelines for managing and preserving electronic files in an architectural firm. Lecture presented at the Architectural Records Conference of the Conservation Center for Art and Historic Artifacts, Philadelphia, PA.

Irving, J. (2000, May). Housing recommendations for architectural records: The sacred and the profane. Lecture presented at the Architectural Records Conference of the Conservation Center for Art and Historic Artifacts, Philadelphia, PA.

Iyer, H. (n.d). Core competencies for visual resource management. Albany: NY: Institute of Museum and Library Services, University of Albany, Department of Information Studies.

Kopatz, K. (Ed.). (2000). Guidelines for the visual resources profession. Laguna Beach, CA: Joint Project of the Art Libraries of North America and the Visual Resources Association.

Kummer, K. (2007). Implementing the federal enterprise architecture records management profile. Scientific Computing, 24(2), 28-30. 
Lathrop, A. (2000, May). Collecting, collection policy, and appraisal of architectural records. Lecture presented at the Architectural Records Conference of the Conservation Center for Art and Historic Artifacts, Philadelphia, PA.

Lowell, W. (2000, May). Establishing intellectual control and access to architectural records. Lecture presented at the Architectural Records Conference of the Conservation Center for Art and Historic Artifacts, Philadelphia, PA.

Lowell, W. (2000, May). A standard approach to arrangement and description of architectural records. Lecture presented at the Architectural Records Conference of the Conservation Center for Art and Historic Artifacts, Philadelphia, PA.

Matarazzo, J. M. \& Connolly, S. D. (1999). Knowledge and special libraries. Boston, MA: Butterworth Heinemann.

Mattix, C. (2000, May). Legal issues for architectural records. Lecture presented at the Architectural Records Conference of the Conservation Center for Art and Historic Artifacts, Philadelphia, PA.

McRae, L. \& Chrisman, L. A. (1991). Comparative study of visual resources collections in libraries and academic departments. Art Documentation, 10(1), 27-30.

Mori, T. (Ed.). (2002). Immaterial/ultramaterial: Architecture, design, and materials. Cambridge, MA: Harvard Design School in association with George Braziller.

Morrison, P. L. (1991). Start-up information centers: How to keep them in business. Special Libraries, 82(1), 19-22.

Nelb, T. R. (2000). Architectural records processes-1950 to present. Lecture presented at the Architectural Records Conference of the Conservation Center for Art and Historic Artifacts, Philadelphia, PA.

Nelb, T. R. (2000, May). Preservation management and planning for architectural records. Lecture presented at the Architectural Records Conference of the Conservation Center for Art and Historic Artifacts, Philadelphia, PA.

Nilsen, M. (1989). Staff responsibilities in visual resources collections. Visual Resources Association Bulletin, 16(1), 11-13.

Noel, S. (1986). Organizing a resource library for architectural offices. Interiors, 86(1017), 201. 
Placzek, A. K. (1983, April). Report on architecture libraries: Scope, organization, standards. Paper presented to the Society of Architectural Historians Education Committee, Philadelphia, PA.

Puglia, S. (2000, May). Reformatting and copying architectural records. Lecture presented at the Architectural Records Conference of the Conservation Center for Art and Historic Artifacts, Philadelphia, PA.

Schachter, D. (2007). Becoming the "go-to" person in your organization raises positive perceptions of your department. Information Outlook, 11(5), 56-57.

Schrock, N. \& Cooper, M. (1992). Records in architectural offices. Cambridge, MA: Massachusetts Committee for the Preservation of Architectural Records.

Shepherd, K. (2000, May). Electronic access to architectural collections. Lecture presented at the Architectural Records Conference of the Conservation Center for Art and Historic Artifacts, Philadelphia, PA.

Smith, B. (Ed.). (n.d.). Space planning for the art library (Occasional Papers No.9). Ottawa, Canada: Art Libraries Society of North America.

Snow, C. (1975). Architects wants and needs for information demonstrated through a university-based information service. ASLIB Proceedings, 27, 112-123.

Sokol, D. (2003). Kids' conneXion: The new Angelo Dongia materials library rescues Parsons students from fabric-sample oblivion. Metropolis Magazine, 22(9), 40.

Special libraries: A guide for management. (1986). Washington, DC: Special Libraries Association.

Special Library Association. (n.d.). State of the market 2000: Results from the Information Services Panel Survey. Retrieved from: http://www.phase-5.com/p5library/isp2000.ppt\#256,1

Staffing Standards Committee. (1996). Staffing standards for art libraries and visual resources collections. (Occasional Paper No. 11). Ottawa, Canada: Art Libraries Society of North America Publications.

Sutton, K. D. (1999). Material whirl. Interiors, 36(2), 1-5.

Tatum, L. (2002). Documenting design: A survey of state-of-the-art practice for archiving architectural records. Art Documentation: Bulletin of the Art Libraries Society of North America, 21(2), 25-31. 
Top 500 Design Firms Sourcebook. (2008). New York, NY: McGraw-Hill.

Wayne, K. M. (1997). Architecture sourcebook: A guide to resources on the practice of architecture. Detroit, MI: M. Wheeler.

Whiteside, A. B., Born, P., \& Bregman, A. A. (2000). Collection development policies for libraries and visual collections in the arts (Occasional Paper No. 12). Laguna Beach, CA: Art Libraries of North America.

Wilson, T. L. (Ed.). (2003). The twenty-first century art librarian. New York, NY: Hawthorne Press. 


\section{Appendix B: Resource Directors Association (RDA) Job Description}

A Resource Librarian's job responsibilities may include:

-Research new products/ materials and educate architecture/design staff

-Meet with manufacturer representatives for current product knowledge

-Manage schedule of continuing education seminars for architects/designers

-Maintain Architectural and/or Interiors Library and/or Sustainable /"Green"

Library

-Maintain Codes + Standards

-Maintain a database system of $\mathrm{A}+\mathrm{D}$ industry resources

-Specify/recommend materials and finishes appropriate to specific project

requirements

-Conduct internal product presentations

-Meet with vendors [and organize samples]

-Marketing

-Space Planning

-Establish finish and furniture palettes

-Fabricate presentation boards and materials

-Manage FF+E documents/ schedules and coordinate with drawings

-Prepare and maintain budgets 


\section{Appendix C: Research, Data, Statistics}

The following list of sources is provided to show the extent of the research conducted

to locate research, data, and statistics on the number of architectural design firm libraries and

librarians in the United States.

American Institute of Architects (AIA) Library and Archives

http://www.aia.org/library_default

Association of Licensed Architects (ALA)

http://www.licensedarchitect.org

Association of Architecture School Librarians (AASL)

http://www.architecturelibrarians.org/

American Institute of Architects: The Business of Architecture: 2006 AIA Firm Survey

American Library Association (ALA)

Library Statistics and Performance Measures

http://web.syr.edu/ jryan/infopro/statacad.html

Research Assembly

http://www.ala.org/ala/ors/researchstatisticsassembly/rasa.htm

Publications

http://www.ala.org/ala/ourassociation/publishing/alaeditions/editions.htm

Library Fact Sheets

http://www.ala.org/ala/aboutala/offices/library/libraryfactsheet/alalibraryfactsheet $1 . \mathrm{cfm}$

Art Libraries Society of North America (ARLIS/NA)

Survey and Publications

http://www.arlisna.org/resources/otherpubs/otherpubs_index.html

Center for Research in Library and Information Management (CERLIM)

http://equinox.dcu.ie/

Coalition of Networked Information (CNI)

http://www.cni.org/publications/

Construction Specification Institute (CSI)

www.csinet.org 
Council on Library and Information Resources (CLIR)

Publications-http://www.clir.org/pubs/pubs.html

Resources-http://www.clir.org/

Digital Libraries Federation (DLF)

http://www.diglib.org/publications.htm

J. Paul Getty Museum Research Institute

Research-http://www.getty.edu/research/institute/

Publications-http://www.getty.edu/research/institute/publications.html

International Council on Archives (ICA)

Publications-http://www.ica.org/en/publications

International Interior Design Association (IIDA)

http://www.rdanet.org/about.html?subsect=responsibilities

International Federation of Library Associations (IFLA)

Statistics and Evaluation-http://www.ifla.org/VII/s22/index.htm

Art Libraries Section-http://www.ifla.org/VII/s30/index.htm

Publications-http://www.ifla.org/ipubs.htm

Information Use Management Policy Institute (IUMPI)

http://www.ii.fsu.edu/

http://www.ii.fsu.edu/work.cfm

Publications-http://www.ii.fsu.edu/publications.cfm

International Organization for Standardization (ISO)

Information Technology Standards

http://www.iso.org/iso/en/stdsdevelopers/index.html

International Coalition of Library Consortia (ICLC)

http://www.library.yale.edu/consortia/statementsanddocuments.html

Library Research Service (LRS)

Research and Statistics about Libraries-http://www.lrs.org/

Library of Congress

Standards-http://www.loc.gov/standards/

Museum, Libraries, and Archives Council (MLA)

Policy, Standards, Publications, Communities-http://www.mla.gov.uk/ 
National Archives and Records Administration http://www.archives.gov/publications/finding-aids.html

National Commission on Libraries and Information Science (NCLIS) http://www.nclis.gov/ Statistics and Surveys-http://www.nclis.gov/survey.htm

National Bureau of Economic Research

Data and Statistics-http://www.nber.org/cgi-bin/get_bars.pl?bar=data

National Council of Architectural Registration Boards (NCARB) http://www.ncarb.org

National Information Standards Organization (NISO)

Standards-http://www.niso.org/standards/index.html

Digital Collections Framework-http://www.niso.org/framework/Framework2.pdf

Online Computer Library Center (OCLC)

Programs and Research-http://www.oclc.org/research/

Publications-http://www.oclc.org/research/publications/default.htm

Primary Research Group (PRG)

Publications-http://www.primaryresearch.com/publications.html

Research Library Group (RLG)

Guides and Tools-http://www.rlg.org/en/page.php?Page_ID=555

Art and Architecture Group-http://www.rlg.org/en/page.php?Page_ID=50

Resources-http://www.rdanet.org/

Society of Architectural Historians (SAH)

http://www.upenn.edu/sah

http://sah.org/

Society of American Archivists

http://www.lib.lsu.edu/SAA/VMhome.html

Society of American Archivists

http://saa.archivists.org/Scripts/4Disapi.dll/4DCGI/directory/directory.html

Special Library Association (SLA)

Research-http://www.sla.org/content/resources/research/index.cfm 
Surveys-http://www.sla.org/content/resources/research/unitsurveys.cfm Information Resources

http://www.sla.org/content/resources/inforesour/index.cfm

Publications-http://www.sla.org/content/Shop/otrpubs/index.cfm

Special Libraries and Information Services Group

http://www.slis.co.za/?q=sitemap

U.S. Census Bureau

Architectural Services-http://www.census.gov/epcd/www/naics.html

U.S. Department of Labor Bureau of Labor Statistics

Architectural, Engineering and Related Services

http://www.bls.gov/oes/current/naics4_541300.htm

Education, Training and Library Occupations

http://www.bls.gov/oes/current/naics4_541300.htm\#b25-0000 


\section{Appendix D: Professional Associations}

- Art Libraries of North America (ARLIS/NA)

- Association of Architectural School Librarians (AASL)

- Architecture Librarians Group (ARCLIB)

- Association of Collegiate Schools of Architecture (ACSA)

- Association of Architecture School Librarians (AASL)

- American Library Association (ALA)

- American Institute of Architects (AIA)

- Association of Licensed Architects (ALA)

- Academy of Certified Archivists (ACA)

- American Society of Interior Designers (ASID)

- American Society for Testing and Materials (ASTM)

- Association of Information Management (ASLIB)

- Construction Specification Institute (CSI)

- Design-Build Institute of America (DBIA)

- International Interior Design Association (IIDA)

- Resource Directors Association (RDA)

- Royal Institute of British Architects-USA (RIDA)

- Special Library Association (SLA)

Architecture, Building Engineering, Construction and Design Caucus http://units.sla.org/caucus/kabc/index.html

- U.S. Green Building Council (USGBC) 
- Visual Resource Association (VRA) 


\section{Appendix E: Directories}

American Library Directory (2008-2009)

Directory of Art Libraries and Visual Resource Collections in North America (1978)

Directory of Special Libraries and Information Centers (2007) Thomson Gale

Profile: The Sourcebook of U.S. Architectural Design Firms (1996 and 2004)

International Federation of Library Association's (IFLA) Art, Architecture and Design Libraries (1995)

International Bibliography of Art Librarianship (1987)

IFLA Directory of Art Libraries (1985)

IFLA Directory of Art Libraries \& Visual Resource Collections in North America (1978)

Library Development Services Bureau's California Library Statistics (2006) 
Appendix F: Survey Instrument

INFORMATION MANAGEMENT PROFESSIONALS AND PROGRAMS

Your Name:

Name of Firm:

NOTE: Questions with an *asterisk require an answer.

\section{MANAGEMENT AND STAFF}

This section identifies management roles and staffing information.

*1) What is your primary job title? If you have more than one job title, please list them in the spaces provided.

Primary Job Title

Secondary Job Title

Tertiary Job Title

2) What is you highest level of education?

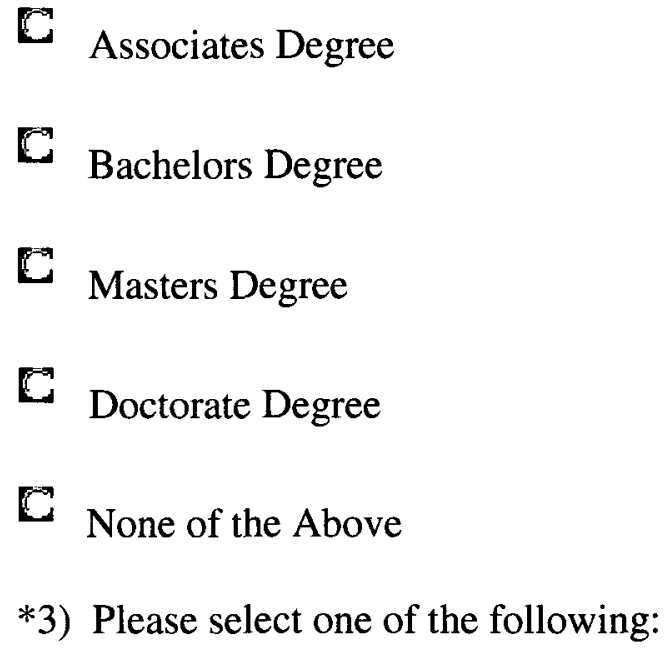

*3) Please select one of the following: 
I have a Library Science Degree

I am working on a Library Science Degree

E None of the Above

*4) Select the actual name, if any, of the information management program(s), department(s), or center(s) that you manage or assist with:

NOTE: If the name(s) differ(s) in any way from those listed (or is a combination thereof, for example, Resource Materials Library) then ONLY select "Other Name(s)" and specify the Name(s) in the space provided.

I manage or assist with resources and/or services only. There is no program, department or center by any name.

T Library

i Archives Department

$\Gamma$ Records Department

$\Gamma$ Information Center

$\Gamma$ Materials Center

$\Gamma$ Resource Center

$\Gamma$ Knowledge Center

$\Gamma$ Other Name(s) 
Specify Other Name(s) Here

5) Select all other information management programs, departments or centers that exist in your office that you DO NOT manage or assist with:
$\Gamma$ Library
$\Gamma$ Archives Department
$\Gamma$ Records Department
$\Gamma$ Information Center
$\Gamma$ Materials Center
$\Gamma$ Resource Center
$\Gamma$ Knowledge Center
$\Gamma$ Other
Specify Other Here

PLEASE NOTE: Programs, departments and centers, and any combination thereof, or by any other name, will be referred to simply as "programs" from this point on. 
6) What is the total number of full and/or part-time people (including yourself) in your office that dedicate paid time to your information management program(s), resources or services?

C One (Me)

2-3 (Myself and Others)

4-5 (Myself and Others)

6-7 (Myself and Others)

8-9 (Myself and Others)

E 10 or More (Myself and Others)

7) Approximately how much paid time TOTAL PER WEEK do full and part-time people (including yourself) dedicate to your information management program(s), resources or the services you provide?

4 hours or Less (Myself plus others)

4.5 up to 8 (Myself plus others)

8.5 up to 12 (Myself plus others)

12.5 up to 16 (Myself plus others)

16.5 up to 20 (Myself plus others)

20.5 up to 24 (Myself plus others) 
24.5 up to 28 (Myself plus others)

28.5 up to 32 (Myself plus others)

32.5 up to 40 (Myself and All Others)

More than 40 hours (Myself plus others)

8) Select only the following tools and resources that are a responsibility of your information management program(s): (Select all that apply)

_ Drawings or Plans

_ Building and Safety Code Information

_ Materials Samples

_ Vendor Catalogs

- Books

_ Journals, Magazines, Newsletters or Newspapers

_ Exhibition or Museum Catalogs

_ Subscription Databases

_ Professional Association Memberships

_ Microforms

_ Slides

_ Digital Images or Photographs

_ Company Web site (Design, development, maintenance)

_ Business or Job Records 
_ Legal or Government Documents

_ Internet Access

_ Intranet (Your firm's internal computer communication network)

_ Extranet (Your firm's shared Intranet network to outside organizations)

_ Other (Specify Here)

9) Select the following job duties that are necessary functions of your information management program(s) or work: (Check all that apply)

_ Developing a strategic plan

_ Budgeting

__ Cataloging or Classifying

_Circulation

_ Color coding

_ Digitization

_ Research (For management or employees)

_ Archival and Preservation

_ Collection Development (Purchase of resources for access/use)

— Vendor Meetings

_ Evaluating (Measuring the value of programs or services)

_ Other (Specify Here) 
10) Select only the following that are expected to be administered to all of you firm's offices nationwide as part of your information management program(s) or work:

_ Library Catalog

_ Drawings or Plans

_ Digital Images or Photographs

_ Vendor Information

__ Building and Safety Code Information

_ Subscription Databases

_ Professional Association Memberships/Information

_ Book Purchases

_ Journal/Magazine/Newsletter/Newspaper Subscriptions (Online or Hard Copy)

_ Intranet

_ Extranet

_ Company Web site

_ Business or Job Records

_ Other Firm Databases

_ Other

Other (Specify Here) 
*11) Do you feel the existing professional literature, training materials, and other sources are sufficient to support your ability to manage or assist with your information management program(s) or work?

Y Nes

11a) If you do not feel they are sufficient:

What professional literature, training materials, or other sources, would you like to see developed to better support your ability to administer or assist with your information management program(s) or work?

\section{Resources}

12) How helpful are the following in supporting your ability to manage or assist with your design firm information management program(s), resources, or services? (Please make a selection for each)

Very Helpful Somewhat Helpful Not Helpful N/A or Do Not Know 
Books (Training or Management)

Book Reviews

Book Buying Services/

Book Sellers

Manuals or Guides -

(Training or Management)

Journal or Magazine

Articles

Theses or Dissertations

Subscription Databases

Professional Association

Membership(s)

Conferences Information/Papers

Continuing Education

Web sites

Blogs

Other

If Other (Specify Here)

\section{PROGRAM INFORMATION}

This section identifies programs and program resources.

13) Outside of paid salaries, is there a budget for the information management

program(s) you manage or assist with, or the resources or services you provide?

C Yes

C No 
Do Not Know

14) Approximately how long has or have the information management program(s) you manage or assist with, or the services you provide, existed in your office?

$$
\begin{aligned}
& \text { Less than } 1 \text { 1-5 5-10 10-15 15-20 20-30 30+ N/A - Do } \\
& 1 \text { Year }
\end{aligned}
$$

You (No program, department, or center)

Library

Archives Department

Records Department

Information Center

Resource Center

Knowledge Center

Other Name

Specify Name Again Here

15) Approximately how much square footage is devoted in your office to your information management program(s), or the resources or services you provide? My Work Space Only My Work Space PLUS all Program Resources

N/A

100 sq. ft. 
200 sq. ft.

300 sq. ft.

400 sq. ft.

500 sq. ft.

600 sq. ft.

700 sq. ft.

800 sq. ft.

900 sq. ft.

1000 sq. ft.

More than 2000 sq. ft.

16) Do any of the following store or provide access to the information, resources, or services you or your information management program(s) provide(s)? (Check any that apply)

$\Gamma$ Intranet

$\Gamma$ Extranet

$\Gamma$ In-house Library Catalog

$\Gamma$ Other Library Catalogs

$\Gamma$ Subscription Databases

$\Gamma$ Other Vendor Web sites 
$\Gamma$

Professional Association Websites

$\Gamma$ Other Web sites

$\Gamma$

Shelves or Racks

$\Gamma$

File Cabinets or Drawers

r

None of the Above

\section{SERVICES}

This section identifies who you program(s) serve and program services.

17) Approximately how many people in your office (and entire firm, if applicable) utilize your information management program's(s') resources or the services you provide? (Please select nationwide as a separate amount that excludes your On-Site Office Total)

\begin{tabular}{|c|c|c|c|c|}
\hline On-Site & Additional & Other Offices Exist, & Other Offices Exist, & No Other Offices \\
\hline & Nationwide & but None Served & but Do Not Know & Exist \\
\hline
\end{tabular}

Number of People

18) Please indicate how active the following end-users are in utilizing your information management program's(s') resources or the information services you provide. (Select "N/A" if Not Applicable)

Very Active Somewhat Active Not Active N/A 
Management

Accounting/Finance

Marketing/Sales

Legal Department

Architects

Interior Designers

Engineers

Other Employees

Specify Department Here

19) Please identify the primary information need for each of the following: (One choice per row)

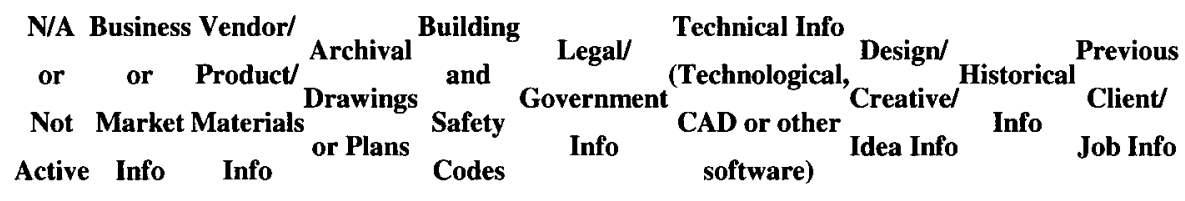

Management

Accounting/Finance

Marketing/Sales

Legal Department

Architects

Interior Designers 
Engineers

20) How are the information needs of the management and employees in your office (or entire firm, if applicable) determined? (Select all that apply)

$\Gamma$ You or co-workers expertise about the industry

$\sqrt{ }$ Networking with other information management professionals outside our office

$r$ Ongoing employee requests

Firm Meetings

$\Gamma$ One-on-one conversations

$\Gamma$ Surveys [Online or Hard Copy]

O Other feedback forms

$\Gamma \quad$ E-mail inquiries

$\Gamma$ Management reports

$\Gamma$ None of the Above

$\Gamma$ Other (Specify Here) 


\section{EVALUATION AND COMMUNICATION}

This section identifies how program services are communicated and if services are evaluated.

21) Are any of the following utilized to evaluate or measure the value of your information management program(s) or the information resources or services you provide? (Select only those that apply)
Surveys or Forms [Web-based, E-mail, Telephone or Hard Copy]
Meetings; Votes or Feedback
$\Gamma$ Circulation Statistics (If items are checked-out)
$\Gamma \quad$ Log-In Information (Library Catalog or Intranet Portal)
None of the Above
Other (Specify Below)

22) Are any of these methods utilized to communicate news about your information management program(s) or the information resources or services you provide to management and employees? (Select only those that apply)
Intranet System Posts
$\Gamma$ E-mail Messages 


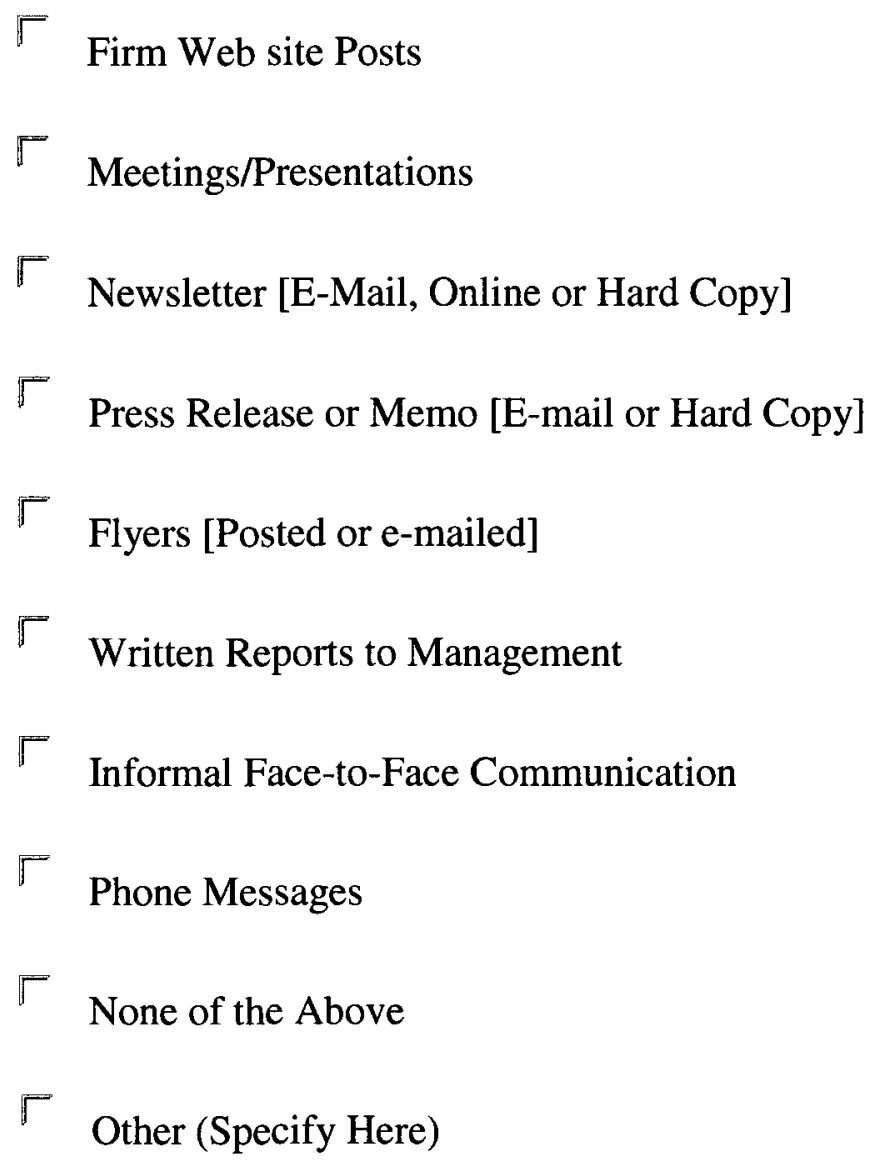

23) List any professional associations you have joined that specifically support your architectural design firm information management work: (Please specify abbreviation and name, if possible, so it can be clearly identified)
1) Abbreviation and Name
2) Abbreviation and Name
3) Abbreviation and Name
4) Abbreviation and Name
5) Abbreviation and Name 
6) Abbreviation and Name

Thank you for completing the survey! Your participation has helped make a valuable contribution to the library science and design firm communities. 


\section{Appendix G: Phone Script}

The researcher, Lynne Kemmer, contacted architectural design firm offices on the phone to obtain information and enlist survey participants.

The script for my initial phone contact with Receptionists as the primary and sole researcher on this project is as follows:

"Hello, Can you tell me if you have a library in your office?

If "Yes" then I ask: "Who in charge of managing or assisting with it?"

If "No" then I ask: "Is there someone in charge of an information program or center by another name in your office?"

If there is a second "No" I will thank them and hang up.

The script for contacting the librarians and IM professionals via telephone that are specified by the Receptionists is as follows:

"Hello, my name is Lynne Kemmer and I am a graduate student in the library and information science program at San Jose State University who is currently working on my thesis. Can you tell me if you are in charge of the library?"

If "Yes" then I say: "I have found through the course of my research that that there is very little information about libraries and librarians or information management work in architectural design firm offices so I have developed an online survey to better understand and support architectural design firm information management practice. 
Your participation is completely confidential and anonymous and only takes about 15 to 20 minutes to complete. Would you be interested in participating?" If "Yes" then I say: "Great! May I have your e-mail address to send you more detailed information about the study and the link to the survey?" If "Yes" then I say: "Thank you! I will send you the information right away. If you could please complete the survey within 2 weeks that would be very helpful in meeting my deadline. I will be happy to share the results with you when it's completed and approved. Please know that until you complete the survey, a follow-up e-mail will be sent to you every week that provides the link to the survey again in case the initial message ended up in your spam folder. Thank you so much! Your participation will make a valuable contribution to the the library science and design firm communities and it is greatly appreciated!"

If "No": "Is there anyone else that is in charge of a library or information program or center in your office?" If "Yes" then I say "Can you tell me who that is?" If "No" then I thank them and hang up. 


\section{Appendix H: Cover Letter}

July 9,2009

Responsible Investigator: Lynne Kemmer

Title of Protocol: INFORMATION MANAGEMENT PROFESSIONALS AND PROGRAMS IN U.S. DESIGN FIRMS: AN EXPLORATORY STUDY

Dear Information Management Professional,

You are being asked to participate in a survey about information management professionals and programs in U.S. design firm offices. Your participation will help to determine if you feel there is sufficient professional literature, training materials and other sources to support your ability to administer or assist with architectural design firm information management work. This research study seeks to clarify information management roles and identify current programs and services. With your help, it will provide a fuller picture of current trends in the design firm industry.

The analysis of the results of this research study may be published, but any information that could identify you or your company will remain ANONYMOUS and CONFIDENTIAL. The survey has 23 questions. If you would like to participate, please follow the link below to your online survey. I would like to ask that you please respond within two weeks so the research study can be completed. Here is a link to your survey: https://www.surveymonkey.com/s.aspx?sm=5BI8Gi8wlr1H5J10N2dUow_3d_3d

Your participation in this study is voluntary and that choosing not to participate in the survey, or in any part of this study, will not affect your relations with San Jose State 
University. No services to which you are otherwise entitled will be lost or jeopardized if you choose not to participate in this study. There are no foreseeable risks in participating in this study. You have the right to withdraw the research at any time without prejudice to your relations with San Jose State University. You have the right not to answer questions you do not wish to answer in the survey questionnaire.

Complaints about this research may be presented to Dr. Debra Hansen, San Jose State University, School of Library and Information Science, PH 714/278-7288.

Questions about research subjects' rights, or research-related inquiries, may be presented to Pamela Stacks, PhD, Associate Vice President, Graduate Studies and Research at 408/924-2480. It is implied that by participating in this study you have read and understand the information communicated in this letter.

Please keep a copy of this letter for your records and contact me if you have questions or concerns, I will be happy to talk with you! You can call me at PH 559/6378889 or send e-mail to: lkemmer@slis.sjsu.edu. I look forward to sharing the results of this research study with you! Thank you for your time.

Best Regards,

Lynne M. Kemmer

Graduate Student

Stan Jose State University

School of Library and Information Science 